\title{
Tectonic Control of the Theistareykir Geothermal Field by Rift and Transform Zones in North Iceland: A Multidisciplinary Approach
}

\section{Maryam Khodayar ${ }^{*}$, Sveinbjörn Björnsson², Sigurður Garðar Kristinsson', Ragna Karlsdóttir ${ }^{1}$, Magnús Ólafsson' ${ }^{1}$, Skúli Víkingsson ${ }^{1}$}

${ }^{1}$ Iceland GeoSurvey (ÍSOR), Reykjavík, Iceland

${ }^{2}$ National Energy Authority of Iceland, Reykjavík, Iceland

Email: *mak@isor.is, *Profnet10@gmail.com, svb@orkugardur.is, sk@isor.is, rk@isor.is, mo@isor.is, sv@isor.is

How to cite this paper: Khodayar, M., Björnsson, S., Kristinsson, S.G., Karlsdóttir, R., Ólafsson, M. and Víkingsson, S. (2018) Tectonic Control of the Theistareykir Geothermal Field by Rift and Transform Zones in North Iceland: A Multidisciplinary Approach. Open Journal of Geology, 8, 543-584. https://doi.org/10.4236/ojg.2018.86033

Received: April 17, 2018

Accepted: June 17, 2018

Published: June 20, 2018

Copyright $\odot 2018$ by authors and Scientific Research Publishing Inc. This work is licensed under the Creative Commons Attribution-NonCommercial International License (CC BY-NC 4.0). http://creativecommons.org/licenses/by-nc/4.0/

\begin{abstract}
This paper presents a multidisciplinary structural analysis of a $165 \mathrm{~km}^{2}$ area in the Northern Rift Zone and the Tjörnes Fracture Zone of Iceland, and unravels the tectonic control of the Theistareykir geothermal field and its surroundings. About 10729 fracture segments (faults, open fractures, joints) are identified in the upper Tertiary to Holocene igneous series. The segments were extracted from aerial images and hillshade, and then analyzed in terms of number of sets, geometry, motions, frequency, and relative age. The correlation with surface geothermal manifestations, resistivity, earthquakes, and occasional well data reveals the critical regional and local fractures at the surface, reservoir level and greater depth. The main conclusions of this study are: 1) The structural pattern consists of N-S rift-parallel extensional fractures and the Riedel shears of the transform zone striking NNE, ENE, E-W, WNW and NW, which compartmentalize together the blocks at any scale. 2) The en échelon segmentation shows strike and oblique slips on the Riedel shears, with a dextral component on the WNW and NW planes and a sinistral component on the NNE to ENE faults. 3) Fractures form under the influence of the transform mechanism and the effect of rifting becomes significant only with time. 4) The WNW dextral oblique-slip Stórihver Fault of the transform zone has a horsetail splay that extends eastwards into the geothermal field. There, this structure, along with few NW, ENE, NNE and N-S fractures, controls the alteration, alignment of fumaroles, emanating deep gases. These fractures also rupture during natural or induced earthquakes. 5) The resistivity anomalies present en échelon geometries controlled by the six fracture sets. These anomalies display clockwise and anticlockwise rotations within the upper $8 \mathrm{~km}$ crustal depth, but at $8 \mathrm{~km}$ depth, only three sets (the
\end{abstract}


N-S rift structures, and the E-W and the NW Riedel shears) are present at the rift and transform plate boundaries. Results of this study are relevant to resource exploration in other complex extensional contexts where rift and transform interact.

\section{Keywords}

Northern Rift Zone of Iceland, Tjörnes Transform Zone, Tectonic Control of

Geothermal Activity, Fractured Reservoir, Earthquakes, Resistivity Anomalies

\section{Introduction}

Rift segments and the transform zones connecting them are integral parts of diverging plate boundaries of any age. Together, they accommodate the spreading and lead to basin formation, petroleum system development, and geothermal activity. Consequently, the role of tectonics is crucial in the geological processes controlling these natural resources. In particular in extensional contexts, geothermal fields are fracture-controlled [1]-[13], where fracture opening or reactivation provides the pathway for magma emplacement (heat source), as well as permeability for fluid circulation.

The study area in Theistareykir is within the Northern Rift Zone (NRZ) and the Tjörnes Fracture Zone (TFZ) (transform zone) in north Iceland (Figures 1(a)-1(c)). The geothermal field in Theistareykir undergoes severe deformation at the intersection of these plate boundaries. Earlier wells drilled in this field targeted the N-S rift-parallel normal faults, which were the most apparent structures and assumed to be the only permeable ones. A recent multidisciplinary analysis, however, provided a new comprehensive tectonic map of both the rift and the transform zones in Theistareykir and surroundings, revealing additional fracture sets and their roles in the control of geothermal activity [14] [15] [16] [17]. This paper presents selected results from these studies. Before discussing the tectonics of the study area, some common features reflecting the general complexities of extensional diverging plate boundaries need to be recalled. Rifts are made of pure extensional fractures and normal faults, often with opening and large vertical offsets, while transform zones develop shear zones with strike-slip and oblique-slip fractures under transtension. Complexities arise in identifying and differentiating some of the fracture sets in areas under the combined influence of rift and transform zones and even within oblique rifting. Examples of those structural features are complex fracture patterns as in Afar [1] [18], Djibouti [19] [20], East African [21] and the Kenyan Rifts [22], and Iceland [23] [24] [25] [26]; pull-aparts on strike-slips [6] [27] [28]; V-shaped ridge and pseudo-faults observed on Iceland shelf [29] [30] and even suggested for onland rift segments in Iceland [31]; en échelon geometry and fracture sinuosity [32] particularly under oblique extension along rift segments [33] [34] [35] such as in 


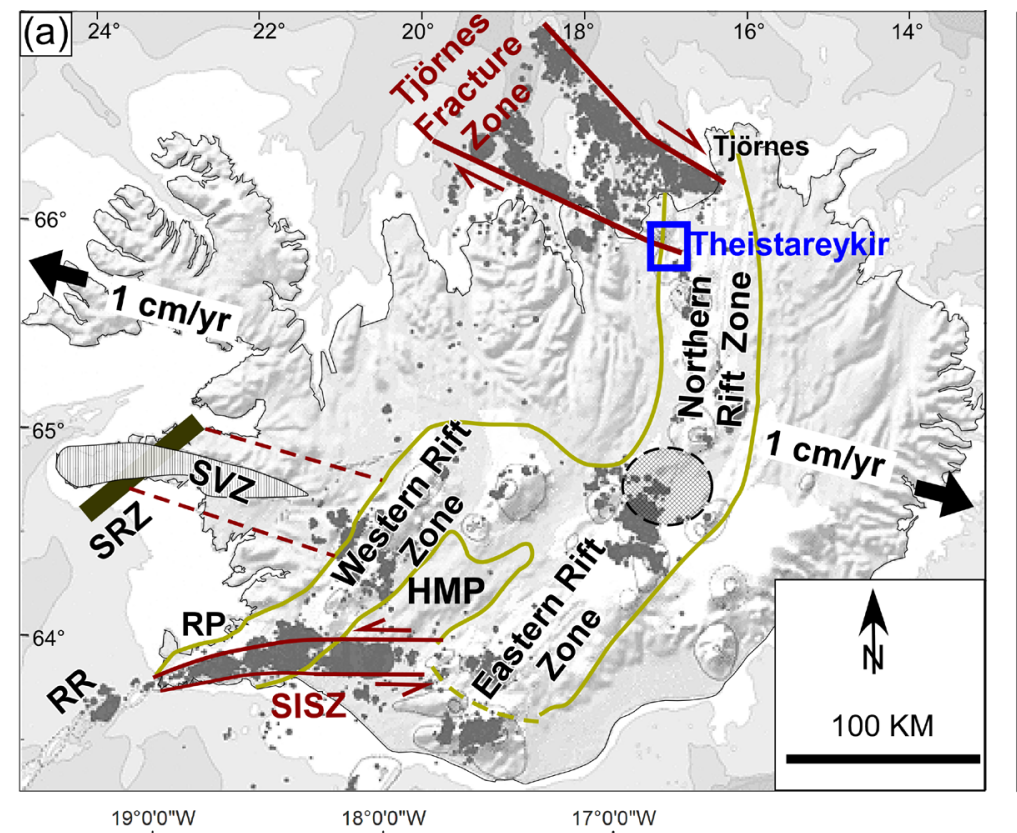

\section{Earthquakes (M1 to 6) \\ /) Active rift segment (loci of high temperature geothermal activity}

N Dextral motion

$\approx$ Sinistral motion

$=: \quad$ Extinct transform zone

Intra-plate volcanism

(1) Centre of hotspot

$\square \quad$ Study area

SRZ: Snæfellsnes Rift Zone (extinct) SVZ: Snæfellsnes Volcanic Zone SISZ: South Iceland Seismic Zone HMP: Hreppar Microplate

RP: Reykjanes Peninsula

RR: Reykjanes Ridge
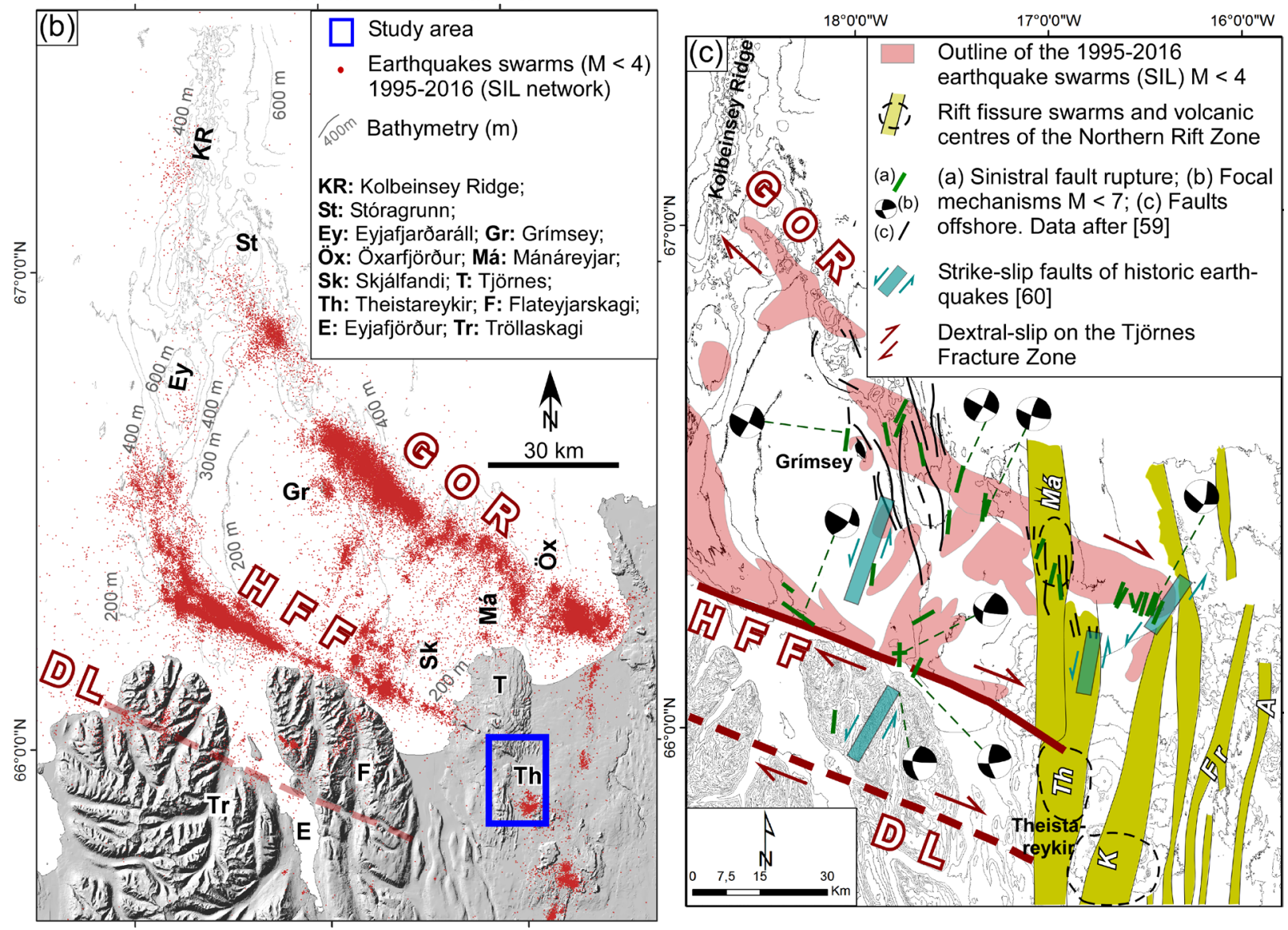

Figure 1. (a) Main tectonic elements of Iceland and location of the study area in north Iceland; (b) Location of the study area in Theistareykir within the rift and transform plate boundaries. The 1995-2016 earthquake swarms $(M<4)$ of the Tjörnes Fracture Zone (TFZ), the Kolbeinsey Ridge and rough bathymetry; (c) Rift fissure swarms, volcanic centres, fault segments of the TFZ, and selected fault plane solutions $(\mathrm{M}<7)$. The fissure swarms are: Th (Theistareykir), Má (Mánáreyjar), K (Krafla), Fr (Fremrinámar), A (Askja). Main segments of the TFZ with dextral strike-slip: GOR (Grímsey Oblique-Rift), HFF (Húsavík-Flatey Fault), DL (Dalvík Lineament). 
Ethiopia [36], Taupo of New Zealand [6] [37] [38] [39] [40], Iceland shelf [13] [41] [42] and in Iceland [43], or oblique extension along a single fracture during dyke injection [44] [45]; stress rotation as in East African Rifts and Gulf of Aden [46] [47] [48] [49].

Early overviews of the tectonics of rift and transform deformation in north Iceland were provided in the 1970's [50] and 1980's [24] [51] [52] [53]. More recent contributions focused on separate aspects of rifting and transform faulting: 1) Mapping of rift structures [54] within active fissure swarms [55] [56]. 2) Geodetic monitoring of deformation [57] [58] and earthquakes [59] [60] [61], covering short-term tectonic activities. 3) Stress analysis [62] [63] [64], and a first comprehensive stress map [65]. 4) Topical features such as local fault geometry and fault termination [66]. The above studies mostly deepened the understanding of present-day rift and transform activity in north Iceland. However, a detailed overview of the tectonic pattern of these plate boundaries, their deformation beyond present-day, and the role of this combined tectonic in geothermal resources is not yet at hand.

The multidisciplinary analysis presented here was a part of geothermal exploration carried out for the National Power Company of Iceland (Landsvirkjun). The analysis led to a new interpretation of rift and transform structures and was used as a basis for the choice of drilling targets and additional wells. The purpose of this paper is to disseminate selected results of that initial investigation as follows:

- A new structural map of the Theistareykir geothermal field and its surroundings is presented, covering an area of $165 \mathrm{~km}^{2}$ at the intersection of the NRZ and the TFZ. As the map results from observations of aerial images and a hillshade, the method of fracture extraction and the image resolution are outlined, followed by the description of the fracture sets and their features.

- The obtained tectonic pattern is further interpreted in terms of style of deformation, the structural weak zones, and the relative fracture evolution in time.

- The correlation of the tectonic pattern with available surface geothermal manifestations, resistivity, selected earthquakes, and occasional well data provides a conceptual model of the geothermal field and its surroundings. The model reveals the critical regional and local fractures at the surface, reservoir level and greater depth.

The main conclusions of this study contribute to the better understanding of rift and transform plate boundaries in Iceland, and are relevant to the exploration of natural resources where rift and transform zones interact in general.

\section{Geological Settings of the Study Area}

The Mid-Atlantic Ridge is expressed as a series of active rift and transform segments in Iceland (Figure 1(a)), which are the loci of volcanism, earthquakes and geothermal activity. The American and Eurasian Plates separate at a rate of 2 
$\mathrm{cm} / \mathrm{yr}$ [67] in the direction of $\mathrm{N} 105^{\circ} \mathrm{E}$ [68] along these plate boundaries. The active rift segments are the NRZ/Eastern Rift Zone (ERZ), and the Western Rift Zone (WRZ) or Reykjanes-Langjökull Rift Zone. The active transform zones are the Tjörnes Fracture Zone (TFZ), connecting the NRZ to the Kolbeinsey Ridge offshore north Iceland (Figure 1(c)), and the South Iceland Seismic Zone (SISZ) that connects the ERZ to the WRZ (Figure 1(a)). West of the WRZ, the plate boundary becomes oblique on the Reykjanes Peninsula (RP) before joining the Reykjanes Ridge offshore (Figure 1(a)). Onland, the oceanic crust consists of basaltic and intermediate lavas, to a lesser degree acidic rocks [69], and reworked sediments, spanning at least $15 \mathrm{Ma}$ [70] [71]. This upper Miocene-present crust is locally eroded down to $1.5 \mathrm{~km}$ [72] [73], and due to the reorganization of plate boundaries, it presents a series of extinct rift segments and at least one micro-plate (Hreppar) [23] [74] [67]. High temperature geothermal fields are present within the active rift segments (particularly at the intersections with transform zones), or in the Reykjanes oblique rift. Low temperature activity is generally located outside active plate boundaries.

The study area in Theistareykir is at the intersection of the NRZ and the TFZ, and the main geological features of these plate boundaries are as follows.

Rift segments consist of fissure swarms, up to $150 \mathrm{~km}$ length and $12 \mathrm{~km}$ width [54] [75], often including a central volcano (with a caldera), normal faults, open fractures and basaltic eruptive fissures. The NRZ has five N-S fissure swarms, and the Theistareykir/Mánáreyjar is the westernmost of them. This swarm consists of old and young N-S extensional fractures contained in a roughly $9 \mathrm{~km}$ wide area onland, stretching to the sea where the last eruption occurred in 1868 [76]. Paleomagnetism, however, suggests that the rock ages in the northern part of Iceland are $15 \mathrm{Ma}$ or at least $10 \mathrm{Ma}$ [71]. The igneous series thus span upper Miocene to present, including basaltic and intermediate lavas, acidic rocks, reworked sediments, hyaloclastites, postglacial lavas (15000 - $8000 \mathrm{yrs)}$ and the picrites erupted 2400 yr BP [54]. Pliocene marine sediments crop out locally only to the northwest of the study area in north Iceland [77] [78].

The TFZ is some $120 \mathrm{~km}$ long, $70 \mathrm{~km}$ wide, and consists of three major WNW lineaments, i.e., the Grímsey Oblique Rift (GOR), the Húsavík-Flatey Fault (HFF), and the Dalvík Lineament (DL) (Figures 1(b)-(c)). Earthquakes, up to M7, have long been identified in this transform zone [79] [80], and episodic swarms [61] [81] indicate dextral and dip-slip motions along the three lineaments. In the absence of obvious fault scarps, GOR is primarily identified by earthquakes, while the HFF has a developed fault plane at the surface, which ruptures during earthquakes [59] [81] [82]. Although the WNW trace of the DL is prominent in the topography, its dextral motion seems to be accommodated by ruptures of NNE sinistral faults on its western portion as during the 1838 to 1963 earthquakes [60]. Regional earthquakes also occur in blocks between the three lineaments where they show dextral strike-slip on shorter WNW/NW faults, and sinistral strike-slip on NNE/NE fracture segments [59] [60], as is the 
case in Theistareykir [83].

GPS monitoring indicates that presently $2 / 3$ of the transform motion across the TFZ is accommodated by the GOR, and $1 / 3$ by the HFF with a slip-rate of 6,6 $\mathrm{mm} / \mathrm{yr}$ [84] [85]. The TFZ, however, has been active since at least 6/7 Ma, during which it accumulated a dextral shift of up to $100 \mathrm{~km}$ [86], and a subsidence in range of hundreds of metres. The complex tectonic evolution over this period includes re-location of spreading centre (rift jump), flexuring and rotation [52] [53] [63] [86] [87], and intense fracturing [14] [15] [51] [87]. The resulting wide range of fracture sets and motions are explained by severe fluctuations in the direction of $S_{H \max }$ stress [64].

The study area is within the Theistareykir/Mánáreyjar Fissure Swarm, and between the HFF and DL lineaments (Figure 1(b) and Figure 1(c)). The high temperature geothermal field is limited to the eastern part of the study area (Figure 2) and identifiable by surface geothermal activity [88]. The 17 wells drilled there reached $2659 \mathrm{~m}$ depth (TVD) and temperatures of $347^{\circ} \mathrm{C}$, yielding sufficient steam to generate 90 MWe electricity. Resistivity anomalies (TEM-MT), however, indicate that the field is larger in the subsurface [89]. The first 9 wells drilled prior to this study used surface alteration, gases [51], chemical evidence [90], and resistivity model [91], and aimed at intersecting N-S and one NW (Tjarnarás) faults [92] [93] [94]. Good permeability was encountered and many depth intervals with alteration, mineral veins, intrusions (sills or dykes) and feeders were identified. However, it was pointed out by [16] that the permeable intervals in the wells are more frequent than the number of $\mathrm{N}-\mathrm{S}$ faults mapped at the surface [51] [95].

The re-evaluated regional tectonics of rift and transform zones in Theistareykir [14], and the correlation with selected data shed more light on the structural control of the geothermal field [15] [16] [17]. This paper offers selected results of that new multidisciplinary analysis.

\section{Method and Data}

The area studied covers three known geological elements (Figure 1 and Figure 2): The HFF, which is the most obvious fault of the TFZ onshore; the Theistareykir rift fissure swarm; and the surface geothermal manifestations in the southeast part of the study area.

Major and subtle identified structures in this study cut the series of upper Miocene (10 - 3,3 Ma), Plio-Pleistocene (3,3 - 0,8 Ma), upper Pleistocene-Holocene (0,8 Ma-present) that include the 15000 - 2400 yrs postglacial lavas [54]. The ease of fracture identification on aerial images depends much on the rock type, exposure, level of erosion, and shadow/light on images. Observations are easier in the older bedrock, which is eroded down to $500 \mathrm{~m}$ crustal depth. In such series, faults have generally accumulated more slips over time and appear with more pronounced traces, thus creating more differentiated topographic highs and lows. The younger postglacial lavas mostly 


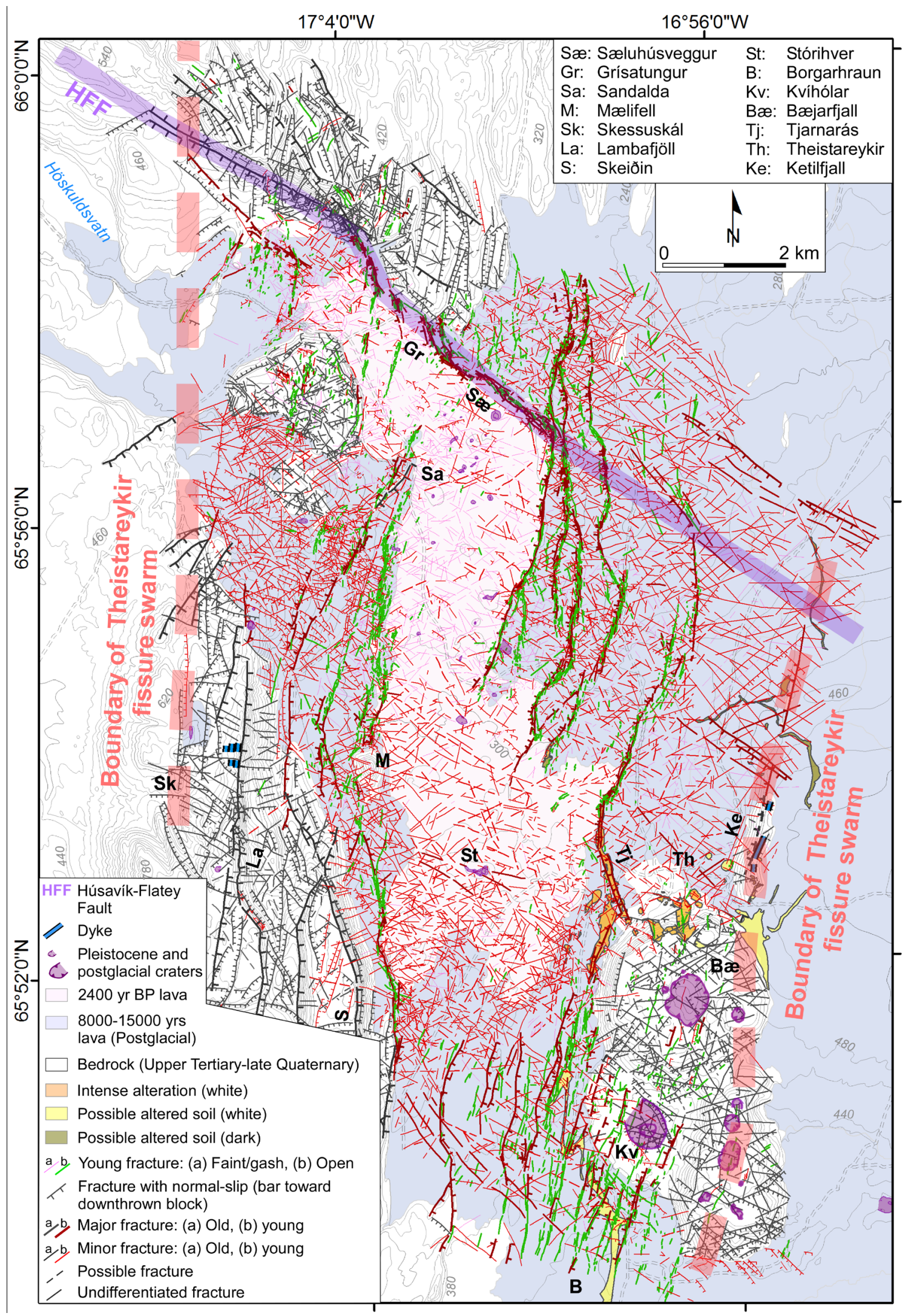

Figure 2. Geological and tectonic elements of Theistareykir and surroundings mapped from eight types of aerial images (modified from [14]). 
occupy the lowland where observations are more difficult as the relief is less pronounced and the younger faults have not yet acquired prominent traces. Considering the size of the area (Figure 2) and the challenges in the observation, all types of aerial images available to this study were used [14], benefiting also from local checking in the Theistareykir outcrops [88] [96]. The methods and data used are as follows.

a) The structures of rift and transform zones were extracted from Spot 5 satellite, orthomaps, stereo pairs of aerial photographs, as well as hillshade (Digital Elevation Model-DEM). The resulting structural map (Figure 2) was used as a reference for the correlation and interpretation of selected surface and subsurface data. The identified structures were manually picked on images. Figure 3(a) shows the resolutions of the aerial images, their features, and methods of fracture extraction. As each type of image is taken at a different altitude and angle, this variety provided different scales and depth for observations. Spot 5 is better suited for the overall fracture traces and regional observations. The orthomaps favour detailed observations of shorter and subtle fractures or for segments with metre-scale dip-slips. The Spot and orthomap images are both rectified, meaning they display correct cartographic coordinates and true North in GIS. The fractures on these images were detected by visual observations and drawn directly in GIS with the confidence of correct strikes.

Stereo pairs of aerial photographs (monochrome) support both regional and local observations. As they are the only image where topography can be observed in relief, they allow the best estimation of the dip direction of faults, the downthrown blocks, and the relative dip-slips. It should be emphasized that identifying the dip direction of fractures is sometimes challenging because the planes in the shallow crustal section are generally steeply-dipping (i.e., $\geq 75^{\circ}$ from horizontal) regardless of fracture type. Stereo pairs aerial photographs are, however, not rectified. Therefore, they were used as side support while drawing the structures in GIS on the basis of Spot and orthomaps.

The combination of all image types ensured the necessary resolutions for the detection of both the obvious and the most subtle fractures at any scale, which is difficult to achieve using only on one or two types of images.

b) The structural map obtained is then analyzed in terms of the number of sets, fracture geometry and motions, fracture frequency (Figures 3(b)-7), and relative fracture age (Figure 8). These qualitative and quantitative analyses provide new insights into the structural pattern of rift and transform zones and their relative evolution in time.

c) Finally, the tectonic pattern is correlated with surface geothermal manifestations (Figure 9), emanating gases (Figure 10), resistivity (Figure 11), selected earthquakes (Figure 12), and occasional well data to identify the critical fracture sets responsible for geothermal activity at the surface, reservoir level and greater depth (Figure 13).

Note that the data at hand do not allow dating the fractures accurately. 


\begin{tabular}{|c|c|c|c|c|c|}
\hline & Features of & rial images & ind methods of & fracture extraction & \\
\hline Image type & Color & Year & \begin{tabular}{|c|} 
Resolution on the \\
ground
\end{tabular} & Rectified & $\begin{array}{c}\text { Method of fracture } \\
\text { extraction }\end{array}$ \\
\hline Spot 5 & Monochrom & 2003 & 2,5 m (per pixel) & \multirow{7}{*}{$\begin{array}{c}\text { Yes } \\
\text { (images are with correct } \\
\text { carthographic coordinates } \\
\text { in GIS, including true } \\
\text { North, and therefore } \\
\text { without distortion) }\end{array}$} & \multirow{7}{*}{$\begin{array}{l}\text { Visual observation of } \\
\text { images in GIS where the } \\
\text { trace and dip direction of } \\
\text { fractures are drawn directly } \\
\text { in GIS }\end{array}$} \\
\hline Spot 5 & Composite & 2003 & 2,5 m (per pixel) & & \\
\hline Spot 5 & Infrared & 2003 & 2,5 m (per pixel) & & \\
\hline Orthomap & Color & 1998 & $0,5 \mathrm{~m}$ (per pixel) & & \\
\hline Orthomap & Black \& White & 1998 & $0,5 \mathrm{~m}$ (per pixel) & & \\
\hline Orthomap & Color & 2007 & $0,5 \mathrm{~m}$ (per pixel) & & \\
\hline Orthomap & Black \& White & 2007 & $0,5 \mathrm{~m}$ (per pixel) & & \\
\hline $\begin{array}{l}\text { Aerial photographs } \\
\text { (a) }\end{array}$ & Black \& White & 1960 and 1961 & $30 \mathrm{~m}$ (per mm) & No & $\begin{array}{c}\text { Visual observations of } \\
\text { stereo images as a mean } \\
\text { of checking and } \\
\text { complementing the } \\
\text { features of fractures drawn } \\
\text { in GIS }\end{array}$ \\
\hline
\end{tabular}

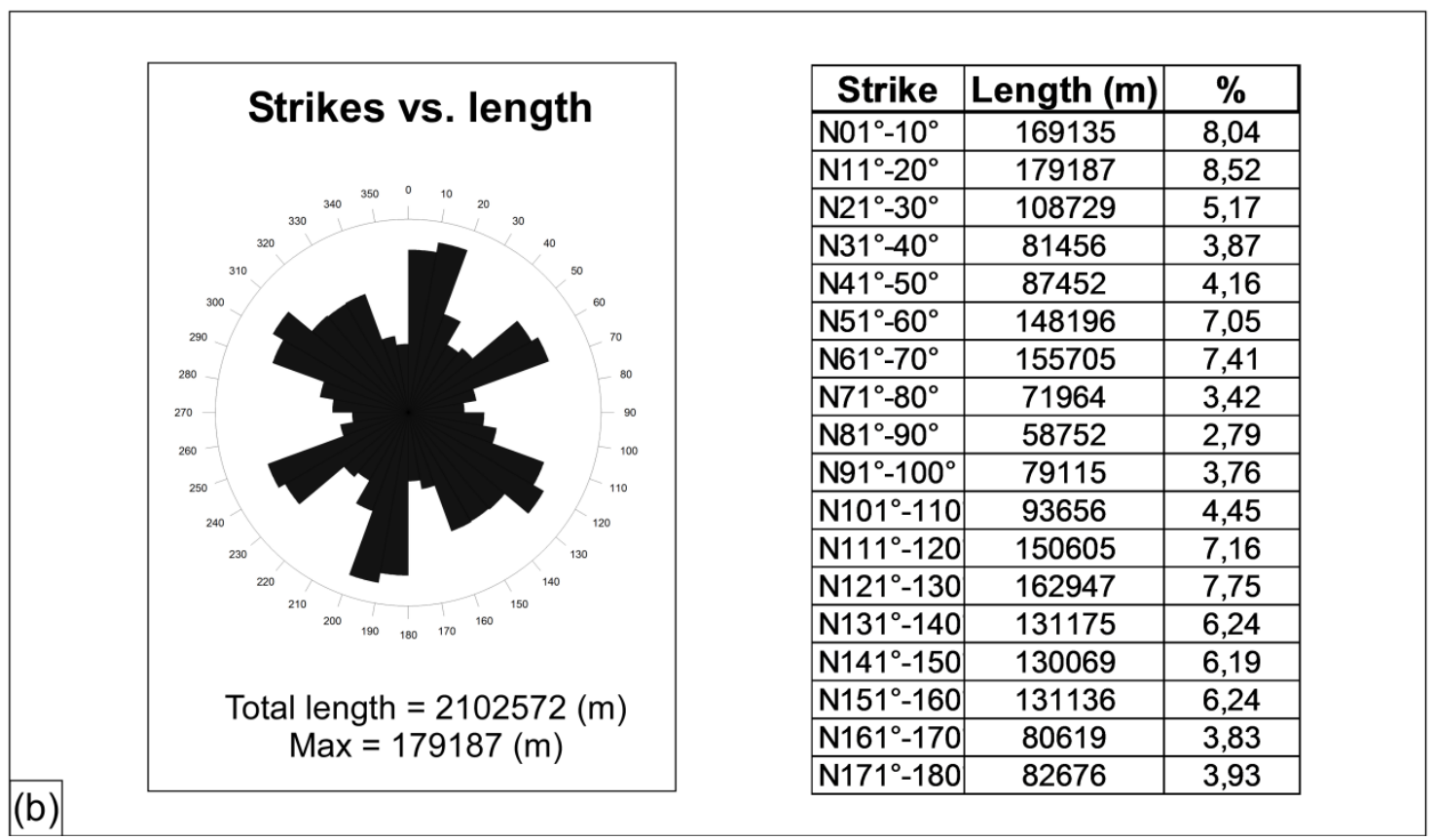

Figure 3. Image types, resolutions, and statistical analysis of the fracture population. (a) Features of aerial images used and methods of fracture extraction; (b) Rose diagram and a table showing the fracture frequency per $10^{\circ}$ of azimuth interval, using fracture strikes vs. fracture length method by [99].

However, in the text, "young" fractures refer to those that are generally fresh, with least slip and often located in lavas < 15000 yrs, while "old" structures are those that have stronger traces and more accumulated slip, often cutting the series $>15000$ yrs.

\section{Multidisciplinary Structural Analysis of Theistareykir}

\subsection{Observation of the Fracture Pattern}

\subsubsection{Fracture Population}

A total of 10,729 fracture segments were identified from aerial images. 

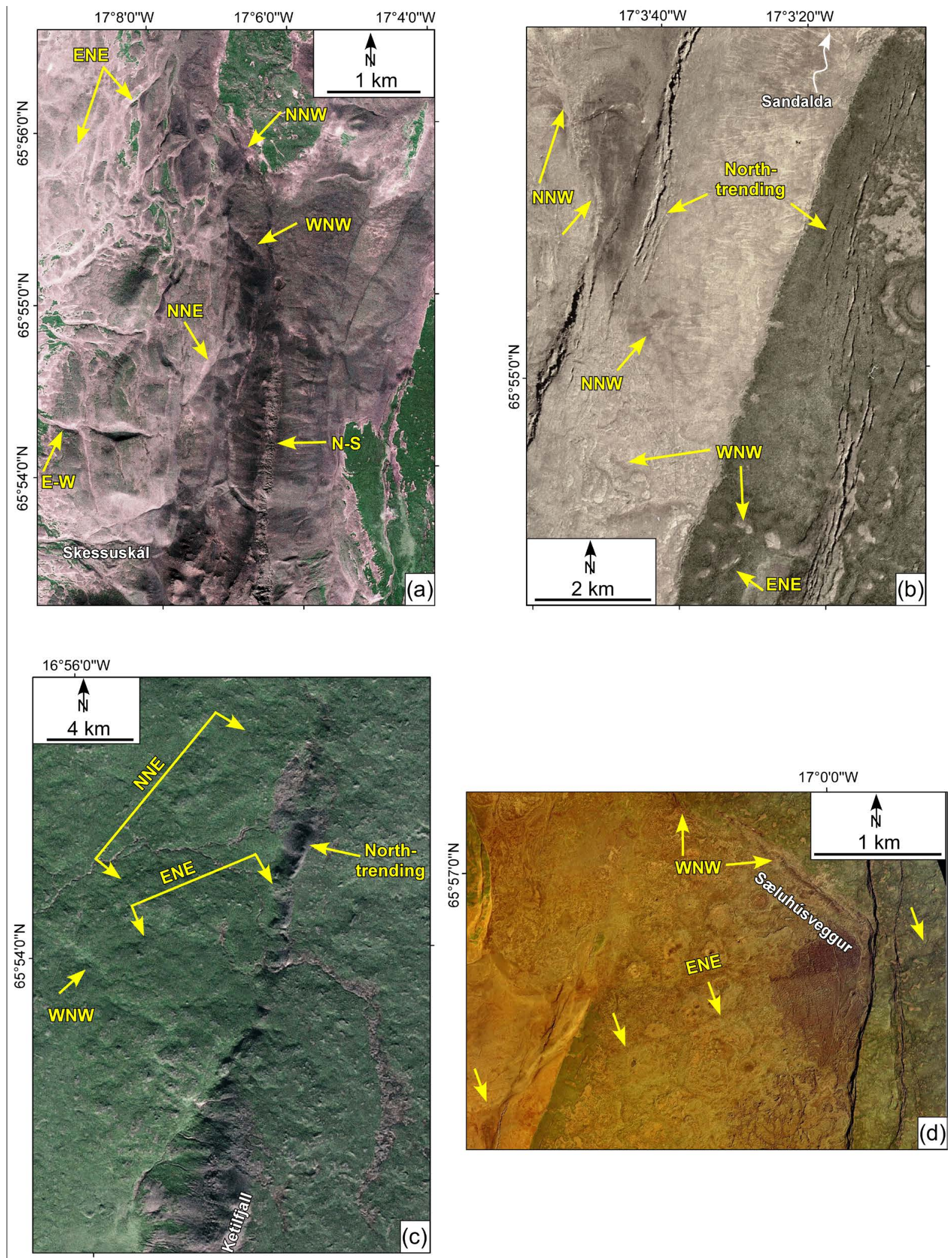

Figure 4. Examples of Riedel shear and extensional fractures along different strikes. (a) Older faults in the upper Tertiary-late Quaternary series; (b) Younger open fractures and subtle segments in the bedrock and the 2400 yr BP lava; (c) Subtle fractures in postglacial lavas (15000 - $8000 \mathrm{yrs);} \mathrm{(d)} \mathrm{Fractures} \mathrm{with} \mathrm{faint} \mathrm{traces} \mathrm{extending} \mathrm{from} \mathrm{the} 2400 \mathrm{yr}$ BP lava (left and centre) into the postglacial lavas (right). 

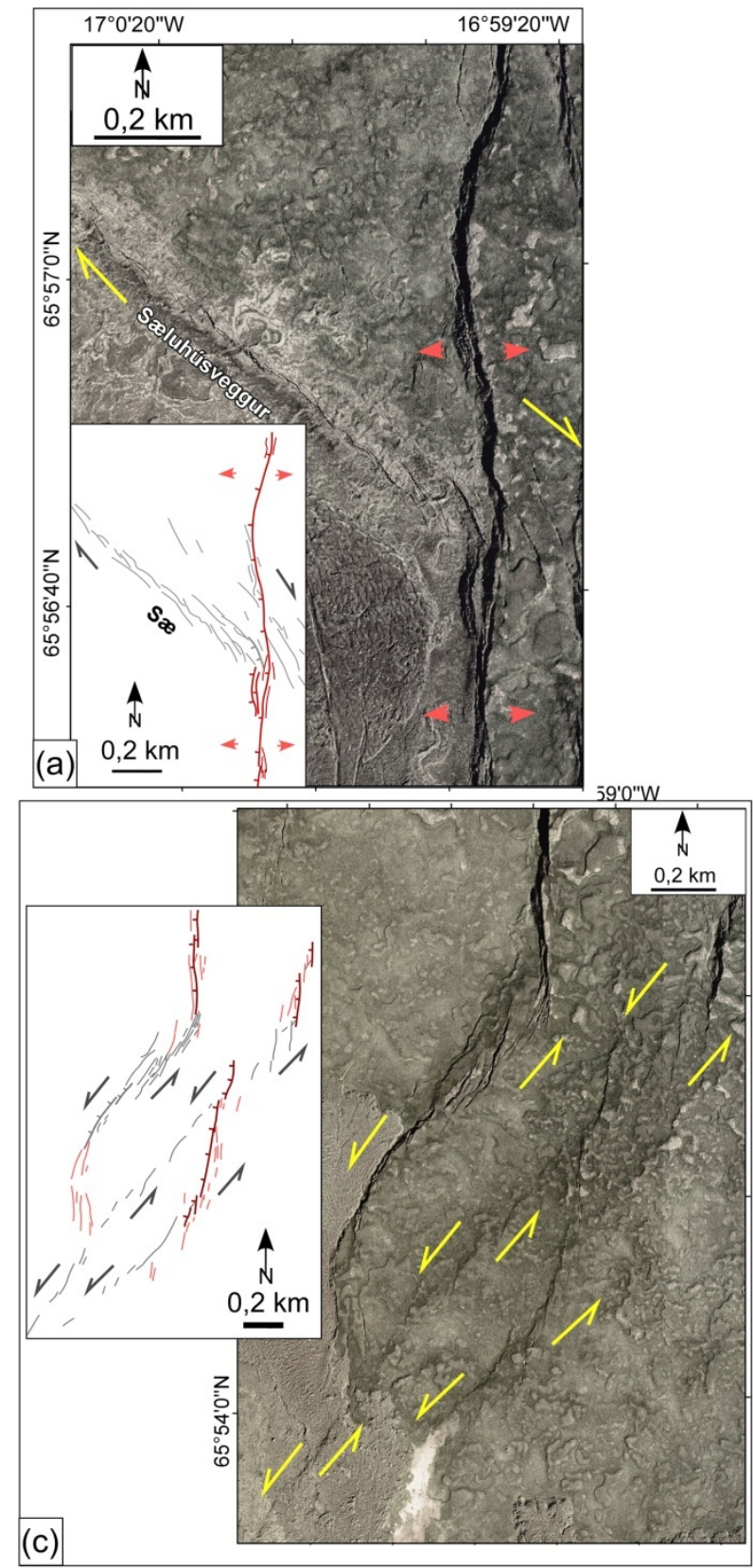
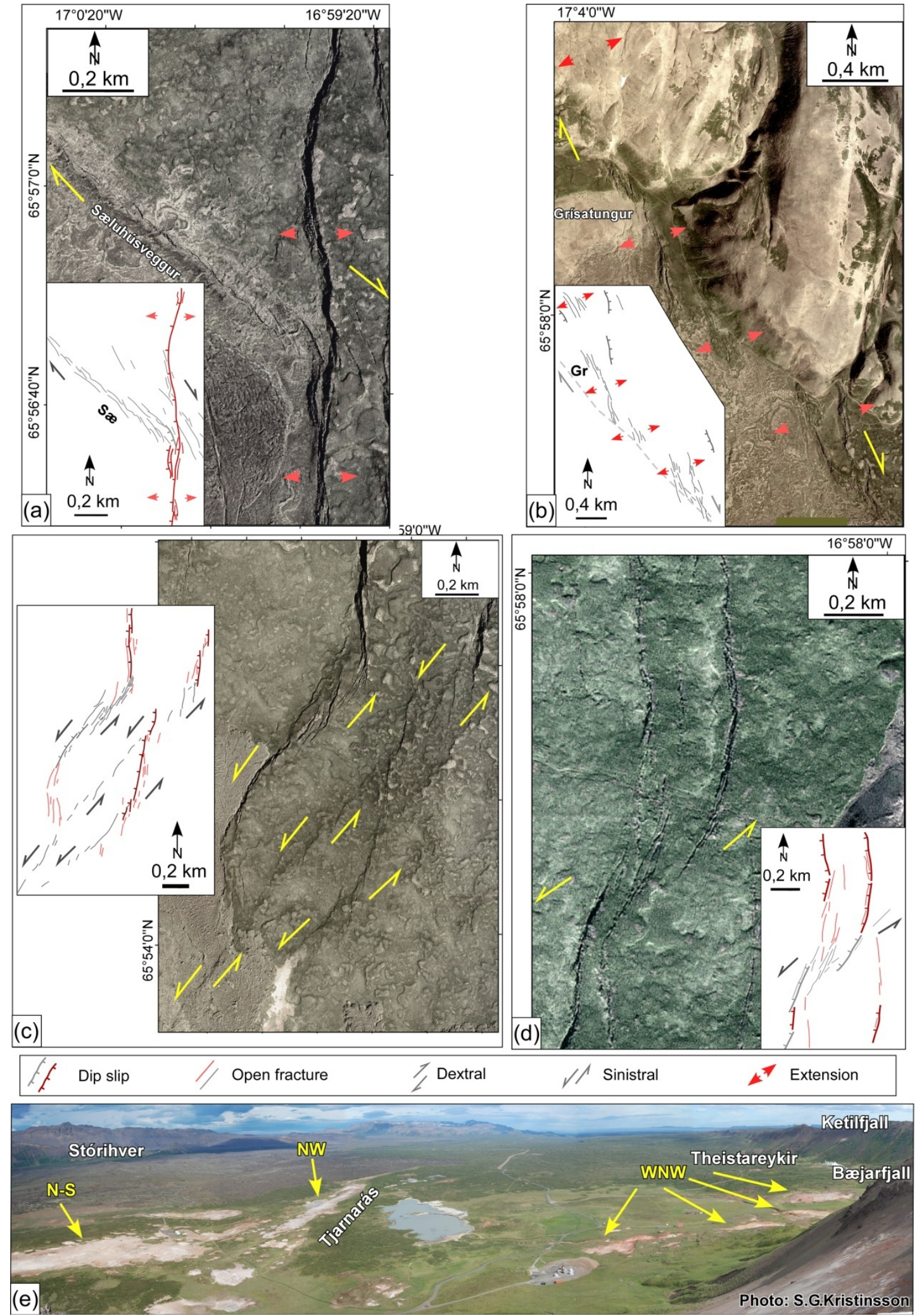

Figure 5. Fracture geometry, motions, and surface geothermal manifestations. (a) and (b) Left-stepping en échelon arrangement of WNW and NW segments, indicating a dextral strike-slip; (c) and (d) Right-stepping en échelon arrangement of NNE to ENE segments, indicating a sinistral strike-slip; (e) Surface alteration aligned N-S, NW and WNW. The WNW altered segments show a clear left-stepping en échelon arrangement, indicative of a dextral strike-slip. 


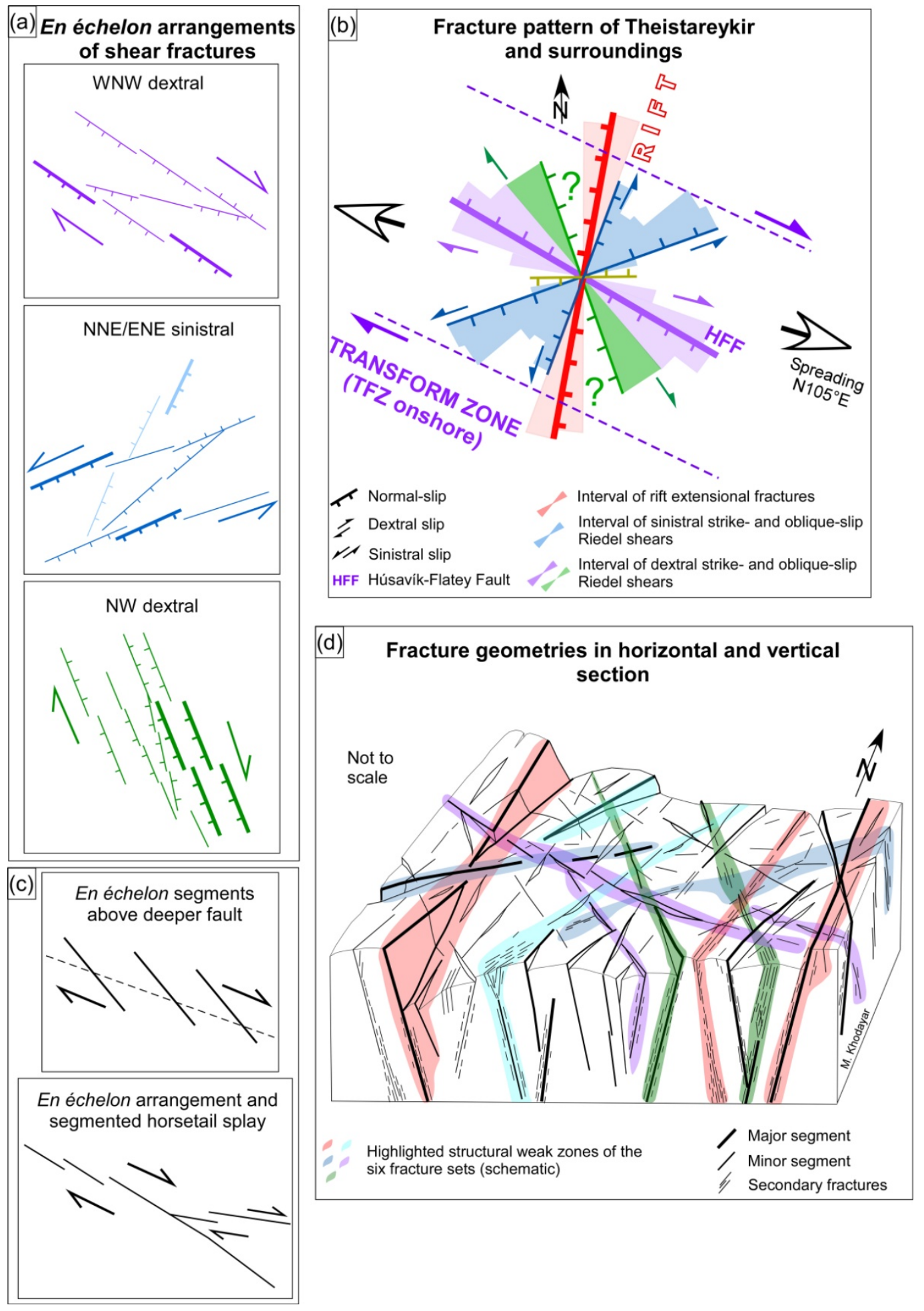

Figure 6. Fault geometries, fault motions, as well as structural weak zones (modified from [14] [15] [16]). (a) En échelon arrangements of segments, and opposite dip directions of fractures; (b) The fracture pattern of rift and transform zones compatible with the spreading at $\mathrm{N} 105^{\circ} \mathrm{E}$; (c) The significance of some fracture geometries. The en échelon segments can be surface expression of deeper strike- and oblique-slip faults, while horsetail splay segments can appear at the termination of any fault set; (d) A schematic block diagram showing the weak zones and how they are defined here based on fracture geometry and the frequency of major, minor or even faint segments. The geometries are valid regardless of whether the main deep structures have fully broken the surface or not. 


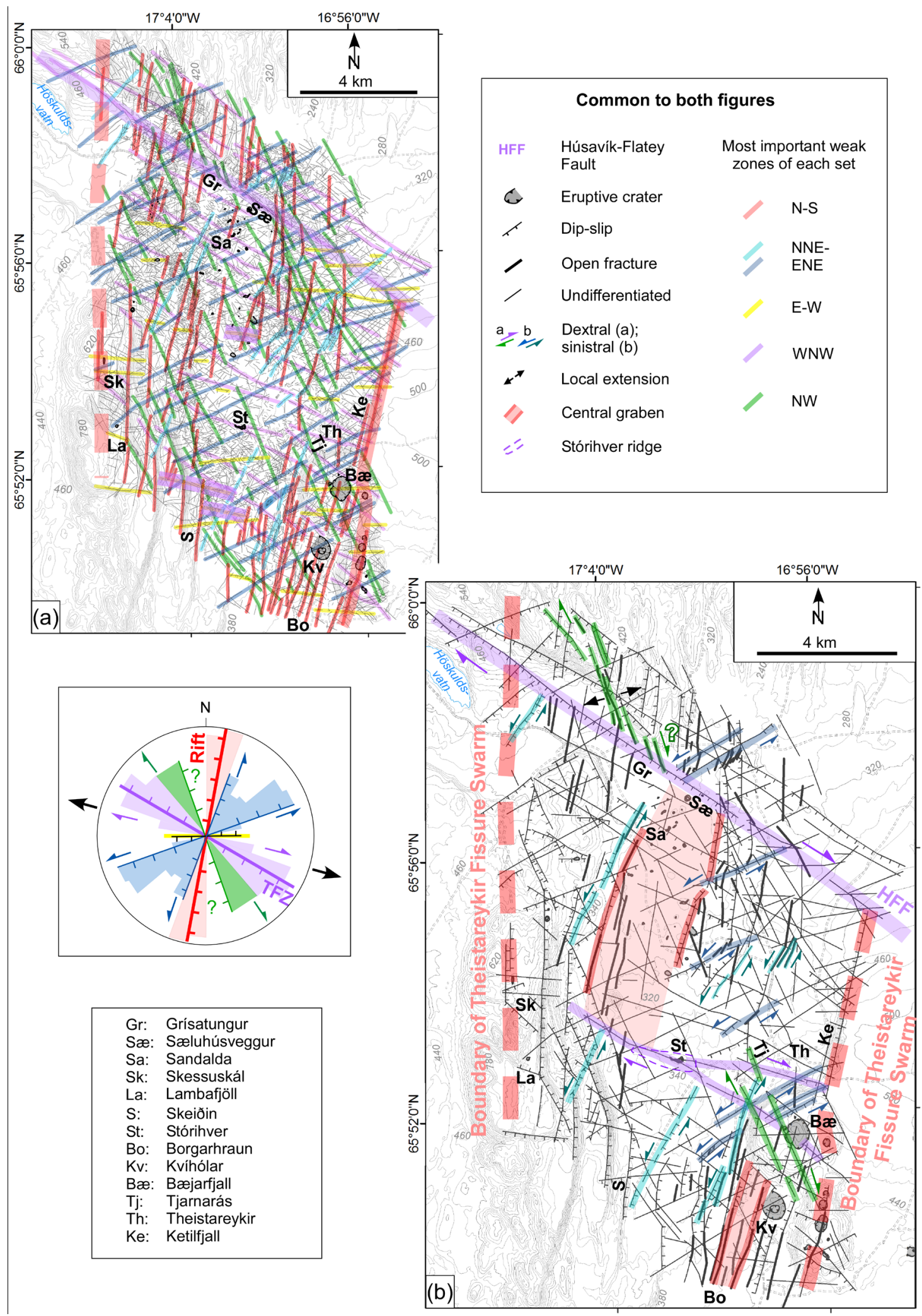

Figure 7. The structural weak zones of each fracture set, their motions and distribution. (a) Fracture segments of the underlying map are highlighted in colors to show the most significant structural weak zones. The sets and their motions are also presented in the same colors in the rose diagram; (b) The highlighted weak zones of Figure 7(a) are simplified as thinner black lines. They are again highlighted with the color codes of each set and shear motions are shown along some of the most prominent structures. 


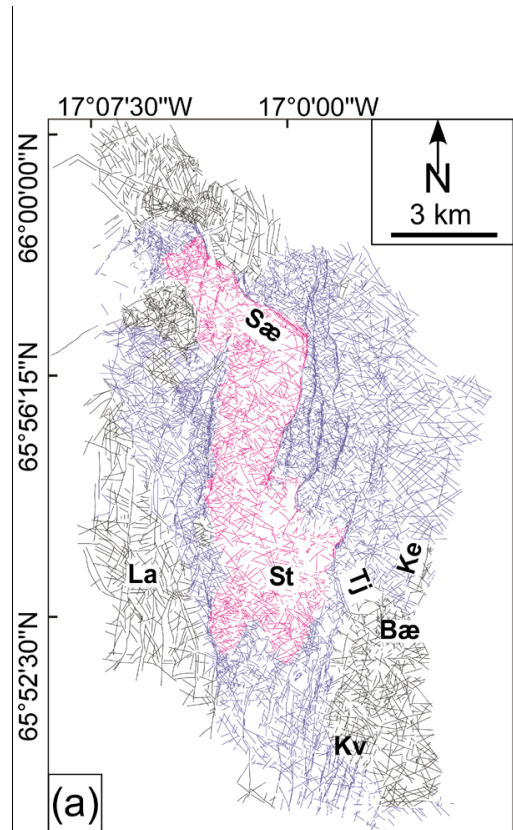

Group (1) fractures: In
the 2400 yr BP
Theistareykir lava
Group (2) fractures:
In Postglacial lavas
(8000-15000 yrs)
Group (3) fractures:
In bedrock > 15000
yrs (Upper Tertiary -
late Quaternary)
Sæ: Sæluhúsveggur
La: Lambafjöll
St: Stórihver
Tj: Tjarnarás
Ke: Ketilfjall
Bæ: Bæjarfjall
Kv: Kvíhólar

\begin{tabular}{|c|c|c|c|c|c|}
\hline Group (1) & Strike & Length (m) & $\%$ & Set $\%$ & \multirow[b]{3}{*}{ N-S } \\
\hline & N01 ${ }^{\circ}-10^{\circ}$ & 13500 & 3,75 & \multirow[b]{2}{*}{9,5} & \\
\hline & $\mathrm{N} 11^{\circ}-20^{\circ}$ & 20531 & 5,70 & & \\
\hline & $\mathrm{N} 21^{\circ}-30^{\circ}$ & 18326 & 5,09 & \multirow{3}{*}{12,6} & \multirow{3}{*}{ NNE } \\
\hline & $\mathrm{N} 31^{\circ}-40^{\circ}$ & 13108 & 3,64 & & \\
\hline & $\mathrm{N} 41^{\circ}-50^{\circ}$ & 14037 & 3,90 & & \\
\hline & $\mathrm{N} 51^{\circ}-60^{\circ}$ & 24796 & 6,88 & \multirow{3}{*}{21,4} & \multirow{3}{*}{ ENE } \\
\hline & $\mathrm{N} 61^{\circ}-70^{\circ}$ & 37141 & 10,31 & & \\
\hline & N71 $1^{\circ}-80^{\circ}$ & 15252 & 4,23 & & \\
\hline & N81 ${ }^{\circ}-90^{\circ}$ & 11550 & 3,21 & \multirow{2}{*}{7,7} & \multirow{3}{*}{ E-W } \\
\hline \multirow{4}{*}{$\begin{array}{l}\text { Total length }=360241 \mathrm{~m} \\
\text { (All strikes) }\end{array}$} & N91 ${ }^{\circ}-100^{\circ}$ & 16013 & 4,45 & & \\
\hline & $\mathrm{N} 101^{\circ}-110^{\circ}$ & 26775 & 7,43 & \multirow{3}{*}{24,4} & \\
\hline & $\mathrm{N} 111^{\circ}-120^{\circ}$ & 29172 & 8,10 & & WNW \\
\hline & $\mathrm{N} 121^{\circ}-130^{\circ}$ & 31846 & 8,84 & & \\
\hline \multirow{5}{*}{$\begin{array}{l}\text { Max. }=37141 \mathrm{~m} \\
\left(\mathrm{~N} 61^{\circ} \mathrm{E}-\mathrm{N} 70^{\circ} \mathrm{E}\right)\end{array}$} & $\mathrm{N} 131^{\circ}-140^{\circ}$ & 23013 & 6,39 & \multirow{3}{*}{17,8} & \multirow{5}{*}{ NW } \\
\hline & $\mathrm{N} 141^{\circ}-150^{\circ}$ & 21050 & 5,84 & & \\
\hline & $\mathrm{N} 151^{\circ}-160^{\circ}$ & 20248 & 5,62 & & \\
\hline & $\mathrm{N} 161^{\circ}-170^{\circ}$ & 16176 & 4,49 & \multirow{2}{*}{6,6} & \\
\hline & $\mathrm{N} 171^{\circ}-180^{\circ}$ & 7707 & 2,14 & & \\
\hline
\end{tabular}

\begin{tabular}{|c|c|c|c|c|c|}
\hline \multicolumn{6}{|l|}{ Grou } \\
\hline & ${\mathrm{N} 01^{\circ}-10^{\circ}}^{\circ}$ & 93879 & 8,09 & \multirow{2}{*}{\multicolumn{2}{|c|}{17,2 N-S }} \\
\hline & $\mathrm{N} 11^{\circ}-20^{\circ}$ & 105848 & 9,13 & & \\
\hline & $\mathrm{N} 21^{\circ}-30^{\circ}$ & 66697 & 5,75 & \multirow{3}{*}{14} & \multirow{3}{*}{ NNE } \\
\hline & $\mathrm{N} 31^{\circ}-40^{\circ}$ & 44763 & 3,86 & & \\
\hline " & $\mathrm{N} 41^{\circ}-50^{\circ}$ & 50793 & 4,38 & & \\
\hline$=$ & $N 51^{\circ}-60^{\circ}$ & 79825 & 6,88 & \multirow{3}{*}{17,2} & \multirow{3}{*}{ ENE } \\
\hline \multirow{4}{*}{ 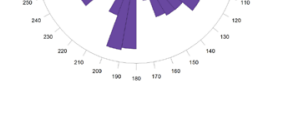 } & N61 ${ }^{\circ}-70^{\circ}$ & 82742 & 7,13 & & \\
\hline & N71 ${ }^{\circ}-80^{\circ}$ & 37263 & 3,21 & & \\
\hline & N81 ${ }^{\circ}-90^{\circ}$ & 30446 & 2,62 & 61 & \multirow{2}{*}{ E-W } \\
\hline & N91 ${ }^{\circ}-100^{\circ}$ & 40172 & 3,46 & 0,1 & \\
\hline \multirow{3}{*}{$\begin{array}{l}\text { Total length }=1159969 \mathrm{~m} \\
\text { (All strikes) }\end{array}$} & $\mathrm{N} 101^{\circ}-110^{\circ}$ & 44209 & 3,81 & & \multirow{3}{*}{ WNW } \\
\hline & $\mathrm{N} 111^{\circ}-120^{\circ}$ & 83456 & 7,19 & 18,6 & \\
\hline & $\mathrm{N} 121^{\circ}-130^{\circ}$ & 88366 & 7,62 & & \\
\hline \multirow{5}{*}{$\begin{array}{l}\text { Max. }=105848 \mathrm{~m} \\
\left(\mathrm{~N} 11^{\circ} \mathrm{E}-\mathrm{N} 20^{\circ} \mathrm{E}\right)\end{array}$} & $\mathrm{N} 131^{\circ}-140^{\circ}$ & 73019 & 6,29 & & \multirow{5}{*}{ NW } \\
\hline & $\mathrm{N} 141^{\circ}-150^{\circ}$ & 72378 & 6,24 & 18,5 & \\
\hline & $\mathrm{N} 151^{\circ}-160^{\circ}$ & 68878 & 5,94 & & \\
\hline & N161 ${ }^{\circ}-170^{\circ}$ & 45377 & 3,91 & 84 & \\
\hline & $\mathrm{N} 171^{\circ}-180^{\circ}$ & 51858 & 4,47 & 8,4 & \\
\hline
\end{tabular}

\begin{tabular}{|c|c|c|c|c|c|}
\hline Group (3) & Strike & Length (m) & $\%$ & Set \% & \multirow{3}{*}{ N-S } \\
\hline & N01 ${ }^{\circ}-10^{\circ}$ & 52652 & 9,04 & \multirow{2}{*}{17,7} & \\
\hline & $\mathrm{N} 11^{\circ}-20^{\circ}$ & 50487 & 8,67 & & \\
\hline & $\mathrm{N} 21^{\circ}-30^{\circ}$ & 31878 & 5,47 & \multirow{3}{*}{13,2} & \multirow{3}{*}{ NNE } \\
\hline & N31 $1^{\circ}-40^{\circ}$ & 23129 & 3,97 & & \\
\hline & $\mathrm{N} 41^{\circ}-50^{\circ}$ & 22058 & 3,79 & & \\
\hline w & N51 ${ }^{\circ}-60^{\circ}$ & 39153 & 6,72 & \multirow{3}{*}{17,3} & \multirow{3}{*}{ ENE } \\
\hline & N61 $1^{\circ}-70^{\circ}$ & 38872 & 6,67 & & \\
\hline & N71 ${ }^{\circ}-80^{\circ}$ & 22928 & 3,94 & & \\
\hline & $\mathrm{N} 81^{\circ}-90^{\circ}$ & 16517 & 2,84 & \multirow{2}{*}{6,7} & \multirow{2}{*}{ E-W } \\
\hline \multirow{4}{*}{$\begin{array}{l}\text { Total length }=582362 \mathrm{~m} \\
\text { (All strikes) }\end{array}$} & N91 $1^{\circ}-100^{\circ}$ & 22374 & 3,84 & & \\
\hline & $\mathrm{N} 101^{\circ}-110^{\circ}$ & 20439 & 3,51 & \multirow{3}{*}{17} & \multirow{3}{*}{ WNW } \\
\hline & $\mathrm{N} 111^{\circ}-120^{\circ}$ & 35113 & 6,03 & & \\
\hline & N121 $1^{\circ}-130^{\circ}$ & 43666 & 7,50 & & \\
\hline \multirow{3}{*}{$\begin{array}{l}\text { Max. }=52652 \mathrm{~m} \\
\left(\mathrm{~N} 01^{\circ} \mathrm{E}-\mathrm{N} 10^{\circ} \mathrm{E}\right)\end{array}$} & N131 $-140^{\circ}$ & 34935 & 6,00 & \multirow{3}{*}{19,2} & \multirow{5}{*}{ NW } \\
\hline & $\mathrm{N} 141^{\circ}-150^{\circ}$ & 36397 & 6,25 & & \\
\hline & $\mathrm{N} 151^{\circ}-160^{\circ}$ & 40258 & 6,91 & & \\
\hline & $\mathrm{N} 161^{\circ}-170^{\circ}$ & 21918 & 3,76 & \multirow{2}{*}{8,9} & \\
\hline (d) & $\mathrm{N} 171^{\circ}-180^{\circ}$ & 29588 & 5,08 & & \\
\hline
\end{tabular}

Figure 8. The statistical analysis of the fracture population in terms of fracture evolution in time. (a) Map of all identified fractures, colored into three groups according to the relative age of their host rocks. The rose diagrams and tables present the frequency of rift and transform fracture sets; (b) Group (1) representing the fractures in the youngest Theistareykir lava (2400 yr BP); (c) Group (2) are the fractures in the postglacial lavas (15000 - $8000 \mathrm{yrs);} \mathrm{(d)} \mathrm{Group} \mathrm{(3)} \mathrm{corresponds} \mathrm{to} \mathrm{fractures} \mathrm{in} \mathrm{the} \mathrm{older} \mathrm{series}$ (late Quaternary-upper Tertiary); On all tables, the N-S rift-parallel fractures and the Riedel shears of the transform zone for which motions could be identified are highlighted in grey. 


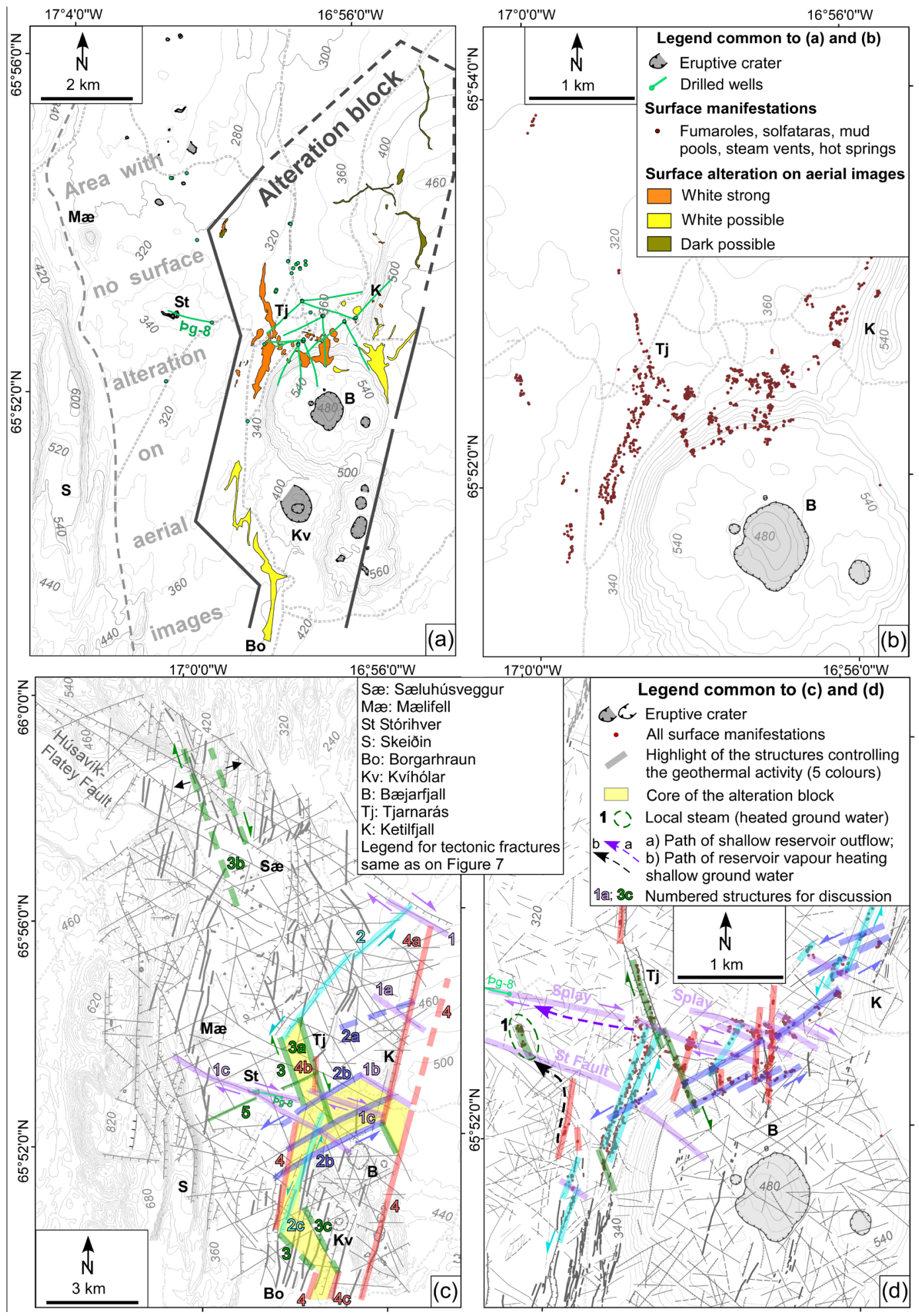

Figure 9. Surface geothermal manifestations and their tectonic control. (a) The alteration block; (b) Distribution of fumaroles, solfataras, mud pools, steam vents and springs [88]. (c) and (d) respectively, the highlight of the rift and transform structures controlling the boundaries of the alteration block, the location of the altered soil within the block, as well as the alignment of surface manifestations. The relevant structures are numbered on Figure 9(c) for discussion in the text. Note that Figure 9(c) uses the simplified weak zones of Figure 7(b) as background, but on Figure $9(\mathrm{~d})$, the background is the detailed fracture pattern of Figure 2 and Figure $7(\mathrm{a})$. 

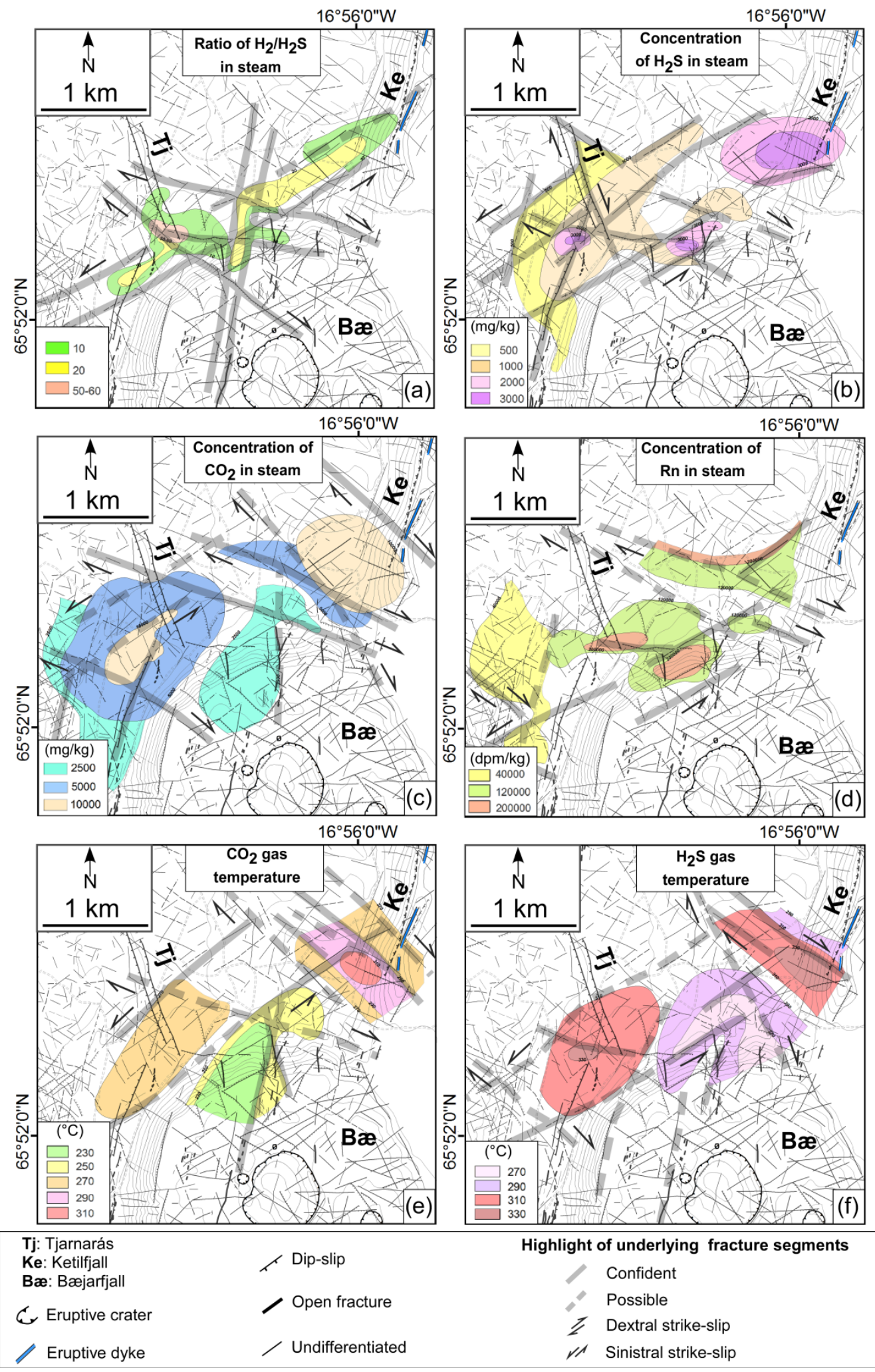

Highlight of underlying fracture segments

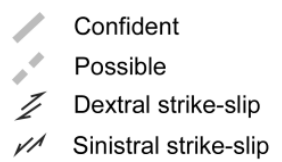

Figure 10. The geothermal gases above the Theistareykir reservoir and the tectonic control of their distribution. (a) to (f) Selected results of geochemistry and gas temperature monitoring from [51] are interpreted here in the light of the structural pattern (highlighted grey faults). Note the dominance of the ENE sinistral and WNW to NW dextral strike-slips of the transform zone, combined with the rift-parallel extensional structural weak zones identified on Figure 7. 

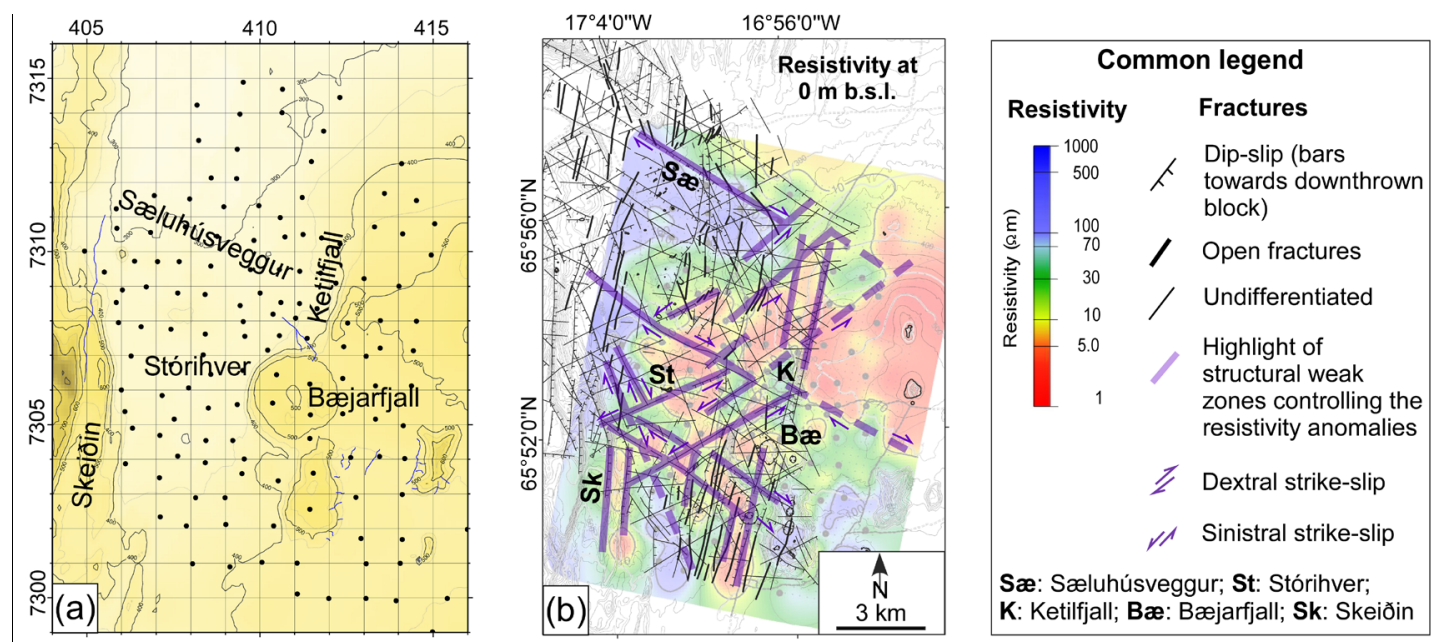

Sæ: Sæluhúsveggur; St: Stórihver;

K: Ketilfjall; Bæ: Bæjarfjall; Sk: Skeiðin
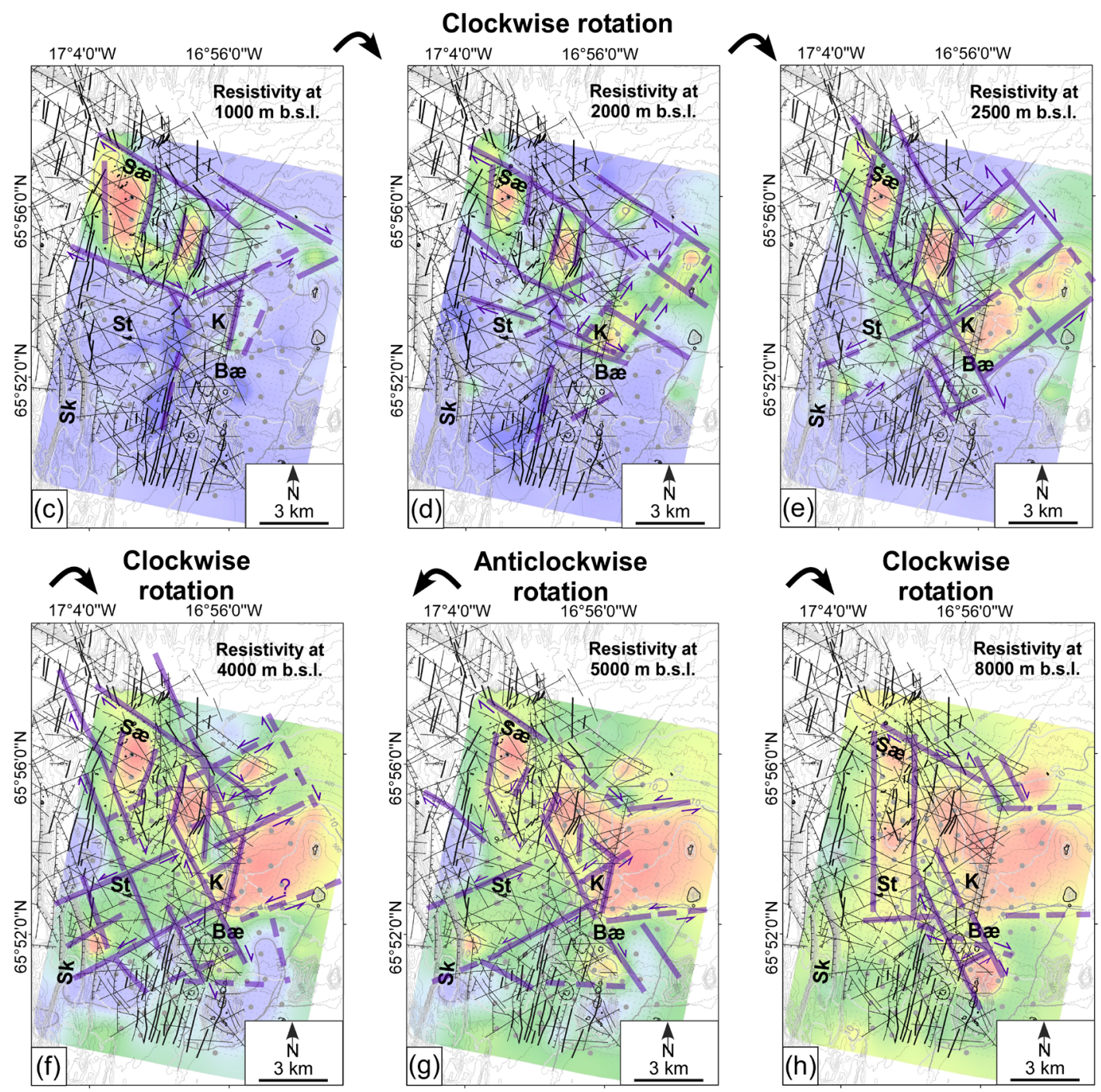

Figure 11. The resistivity anomalies interpreted in the light of the tectonic pattern of rift and transform zones. (a) Frame and data points of TEM/MT resistivity surveys [89] [91]. (b) to (h) The geometry of resistivity anomalies at seven selected depths is interpreted here in the light of the structural weak zones (modified from [15] [16]). The resistivity anomalies are controlled by the WNW, NW, ENE and E-W Riedel shears, and the N-S rift-parallel deep structures. They also show a gradual clockwise rotation between 0 and $4000 \mathrm{~m}$ b.s.l., an anticlockwise rotation at 5000 to $6000 \mathrm{~m}$ b.s.l., and a clockwise rotation again at $8000 \mathrm{~m}$ b.s.l. 

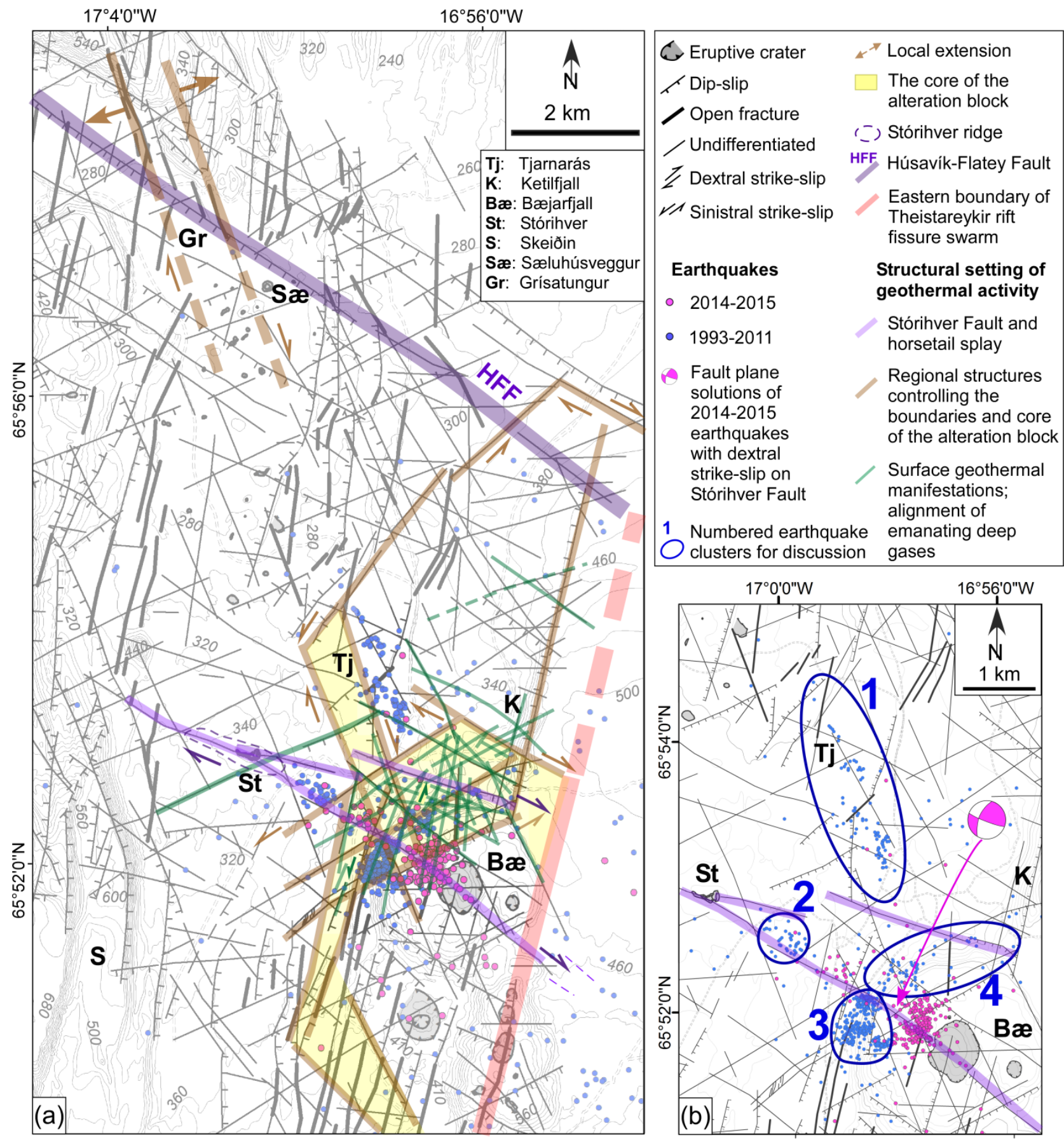

Figure 12. The main results of the multidisciplinary structural investigations (1). (a) Structures controlling the boundaries and core of the alteration block, the geothermal manifestations and the distribution of geochemical components, combined with the 1993-2011 [83] and the 2014-2015 earthquakes [104]. Note that the earthquakes of both datasets form several lineaments matching the suggested fracture traces; (b) A closer look at both earthquake sets and the structural pattern where in particular the 2014-2015 earthquakes fall on the trace of the WNW Stórihver Fault.

The features used for the preparation of the structural map (Figures 2-5) are: 1) The stratigraphy [54], grouped into three relative rock ages. These are the older be drock (upper Miocene-late Quaternary), the postglacial lavas aged 15000 8000 yrs, and the youngest Theistareykir lavas dated 2400 yr BP [95]. 2) Fracture 


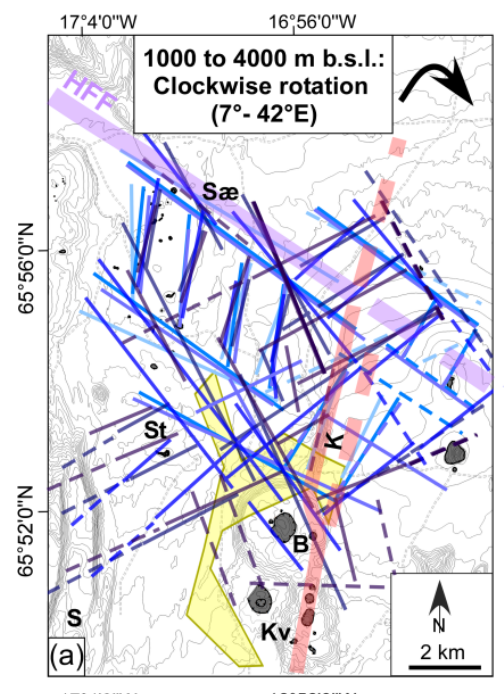

\begin{tabular}{|c|c|c|c|}
\hline $\begin{array}{c}\text { Depths in } \\
\text { (m) b.s.I }\end{array}$ & $\begin{array}{c}\text { Strike-ranges of structures } \\
\text { per depth (most common } \\
\text { structures in bold) }\end{array}$ & $\begin{array}{l}\text { Sense of } \\
\text { rotation }\end{array}$ & $\begin{array}{l}\text { Amount of rotation of } \\
\text { fracture sets inside } \\
\text { depth groups }\end{array}$ \\
\hline 0 & 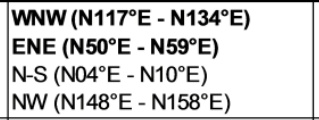 & & \\
\hline 500 & 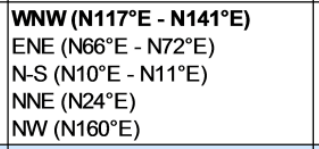 & Clockwise? & \\
\hline 1000 & 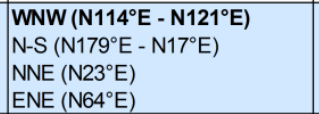 & Clockwise & \multirow{6}{*}{$\begin{array}{c}7^{\circ} \mathrm{E} \text { (N-S) } \\
41^{\circ} \mathrm{E}(\mathrm{NNE} \text { to } \mathrm{ENE}) \\
42^{\circ} \mathrm{E} \text { (WNW to NW/NNW) }\end{array}$} \\
\hline 1500 & 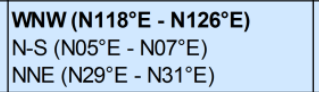 & Clockwise & \\
\hline 2000 & 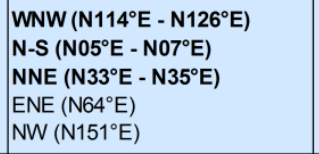 & Clockwise & \\
\hline 2500 & 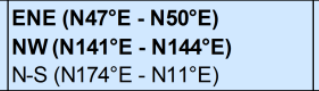 & Clockwise & \\
\hline 3000 & $\begin{array}{l}\left.\text { ENE (N56 } 6^{\circ} E-N 62^{\circ} E\right) \\
\text { NW-NNW }\left(N 145^{\circ} E-N 155^{\circ} E\right) \\
\left.\text { N-S (N10 } E-N 15^{\circ} E\right) \\
\left.\text { NNE (N21 } 1^{\circ} E\right)\end{array}$ & Clockwise & \\
\hline 4000 & 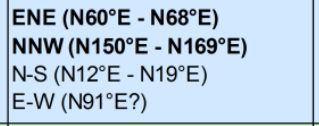 & Clockwise & \\
\hline 5000 & 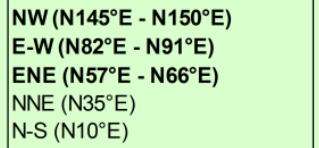 & Anticlockwise & \multirow{2}{*}{$\begin{array}{c}4^{\circ} \mathrm{W}(\mathrm{NNE}) \\
14^{\circ} \mathrm{W}(\mathrm{ENE}) \\
18^{\circ} \mathrm{W}(\mathrm{N}-\mathrm{S}) \\
20^{\circ} \mathrm{W}(\mathrm{NNW} / \mathrm{NW} \text { to } \mathrm{WNW})\end{array}$} \\
\hline 6000 & 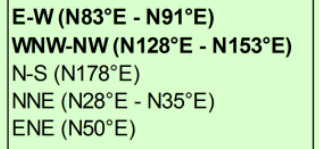 & Anticlockwise & \\
\hline (d) $^{8000}$ & 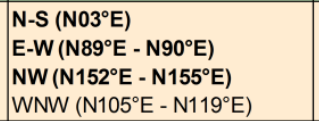 & Clockwise & $\begin{array}{c}3^{\circ} \mathrm{E}(\mathrm{E}-\mathrm{W}) \\
5^{\circ} \mathrm{E}(\mathrm{N}-\mathrm{S}) \\
14^{\circ} \mathrm{E}(\mathrm{WNW} / \mathrm{NW})\end{array}$ \\
\hline
\end{tabular}
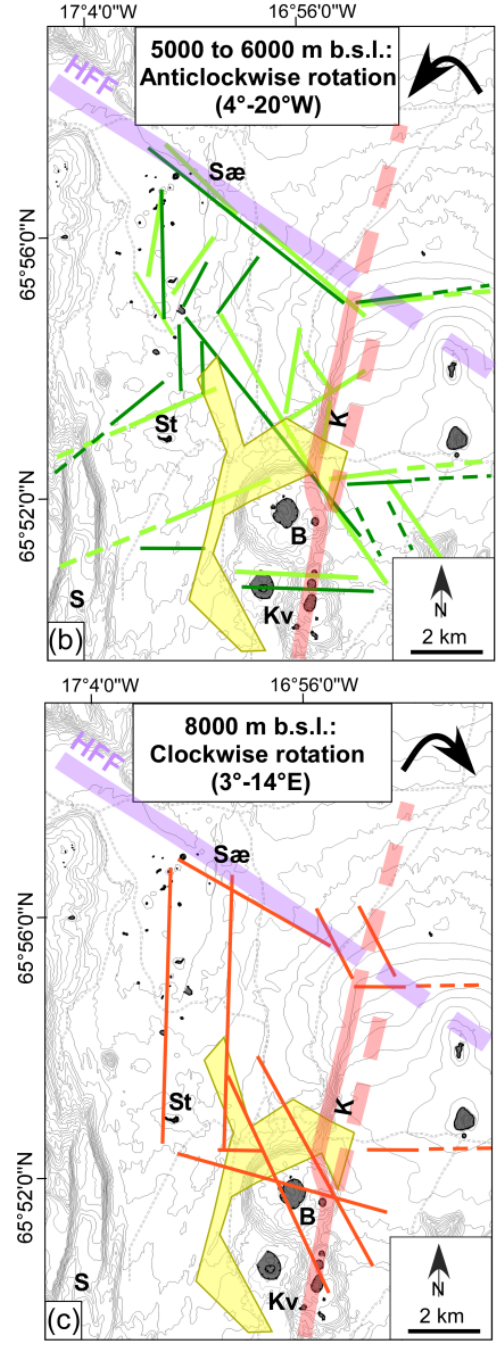

\section{Cruptive crater \\ Outline of the core of alteration block}

Húsavík-Flatey Fault (Transform segment)

Eastern boundary of Theistareykir rift fissure swarm (likely)

Sæ: Sæluhúsveggur; K: Ketilfjall; St: Stórihver; B: Bæjarfjall; Kv: Kvíhólar; S: Skeiðin
Tectonic lineaments controlling the resistivity anomalies at depth (m b.s.I.)

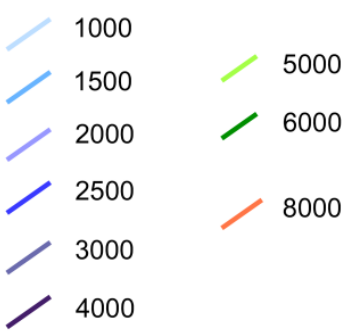

Figure 13. The main results of the multidisciplinary structural investigations (2). (a) to (c) Resistivity anomalies at selected depths between 1000 and $8000 \mathrm{~m}$ b.s.l., and their tectonic control showing gradual rotations within each depth-interval. The rotations are clockwise at 1000 to $4000 \mathrm{~m}$ b.s.l., anticlockwise at 5000 - $6000 \mathrm{~m}$ b.s.l., and clockwise again at $8000 \mathrm{~m}$ b.s.l. The outline of the alteration block is also shown for reference; (d) The table summarizes in detail the strike ranges of the structures in the upper 8000 $\mathrm{m}$ b.s.l., with the most dominant sets highlighted in bold. 
segments, classified in terms of their relative age (younger and older), trace (major, minor, faint), types (open fracture, normal-slip, undifferentiated fractures, and then further analyzed geometrically for strike-slip motions) [14]. 3) Lava tubes and lava channels, mapped to distinguish them from possible fractures, along with Pleistocene and postglacial craters. 4) Surface geothermal manifestations, outlined and labeled as low to high.

Due to the shallow level of erosion, very few appear at the surface. In fact, less than 10 of all mapped segments are dykes, and they crop out far to the east and west of the mapped area (Figure 2), in accordance with the field mapping of [54] [92]. The mapped fractures are thus mostly a-magmatic, but this does not exclude that dykes can arrest at depth, creating surface extensional fractures or grabens, e.g. [36] [97] [98].

It is emphasized that 10729 is not the total number of faults cutting the series as a single fault consists of several segments along its trace, regardless of age.

The mapped structures are at different stages of their evolution during which, segments coalesced, accumulated displacement, and some evolved into major structures (Figures 4(a)-4(d) and Figures 5(a)-5(d)). The length of individual segments forming a single structure can be as short as $\sim 5 \mathrm{~m}$ and as long as $5000 \mathrm{~m}$. Generally, older segments are the longest with sharper traces in the topography and a greater dip-slip in the series. Younger fractures are shorter, fainter in traces (hair-like) and with much less or no dip-slip. Hence, the difficulties in identifying them in outcrops. Minor segments have relatively well visible traces on images, but their slip has not lead to significant changes in the topography. Minor segments can be on the trace of a major and longer structure.

Segments labeled as faint/gash have the least prominent traces, mostly because they are young and have not been subject to major or repetitive deformation. Undifferentiated fractures can have a mild or a strong trace, but their displacement could not be determined because they are either prominent joints or even strike-slips without marker horizons to determine their sense of motion. In some cases, uncertainty did not allow estimating towards which direction a normal fault dips. Possible fractures are breaks in the ground where either their exact trace or their existence cannot be confirmed due to poor exposure.

\subsubsection{Fracture Frequency}

Fracture frequency is one of the many important outcomes of this investigation (Figure 3(b)). An attempt was made to find the most common fractures by counting the strike of each of the 10729 segments, but the method gave an erroneous result. The reason is that a single major long segment was counted only once, but young minor fractures consisting of several short segments were counted as many times as the number of segments along the fracture trace. Therefore, a method conceived by [99] was used in which the fracture frequency in a given set is estimated by adding up the length of all segments in the same $10^{\circ}$ strike-interval. The rose diagram obtained from this method (Figure 3(b)) reflects more coherently the frequencies in accordance with the visual assess- 
ment of fractures on the map (Figure 2 and Figure 3(b)).

It is emphasized that this section describes the fracture frequency only in terms of peaks of fractures that stand out compared to the rest of the fracture population (Figure $3(\mathrm{~b})$ ). At this stage, the statistical analysis does not take into account the sense of motions and the fracture types of rift and transform zones, which are discussed in the following section. Therefore, the fracture sets described here (Figure 3(b)) may not necessarily have the same wide strike-ranges as when the fracture sets are defined on the basis of their motions (Figure 8).

The present statistical analysis shows that fractures with four strike-ranges stand out (Figure 3(b)): N-S (N01 $\left.{ }^{\circ}-\mathrm{N} 20^{\circ} \mathrm{E}\right)$, ENE (N51 $\left.{ }^{\circ}-\mathrm{N} 70^{\circ} \mathrm{E}\right), \mathrm{WNW}$ $\left(\mathrm{N} 111^{\circ}-\mathrm{N} 130^{\circ} \mathrm{E}\right.$ ), and $\mathrm{NW}$ (fractures ranging equally from $\mathrm{N} 131^{\circ}-\mathrm{N} 160^{\circ} \mathrm{E}$ ). The peak of $\mathrm{N} 11^{\circ}-\mathrm{N} 20^{\circ} \mathrm{E}(8,52 \%)$ indicates that the most frequent individual fractures are N-S, but the N-S as a set represents only $16,6 \%$ of the total fracture population. The ENE set accounts for $14,5 \%$ with a peak at $\mathrm{N} 61^{\circ}-\mathrm{N} 70^{\circ} \mathrm{E}(7,41 \%)$, and the WNW $14,9 \%$ with a peak at $\mathrm{N} 121^{\circ}-\mathrm{N} 130^{\circ} \mathrm{E}(7,75 \%)$. The NW set covers three equal $10^{\circ}$ strike-interval (6,19\% to $6,24 \%$ of the fracture population), but combined, they seem the most frequent fractures (18,70\%). A less outstanding peak shows a NNE set $\left(\mathrm{N} 21^{\circ}-\mathrm{N} 30^{\circ} \mathrm{E}\right)$ occupying some $5,17 \%$ of the population.

The E-W fractures appear clearly as a separate set on the structural maps with a strike-range of $\mathrm{N} 81^{\circ}-\mathrm{N} 100^{\circ} \mathrm{E}$ (Figure 2 and Figure $7(\mathrm{a})$ ). Statistically, however, the E-W set represents $6,55 \%$ of the population although its peak $\left(\mathrm{N} 91^{\circ}-\mathrm{N} 100^{\circ} \mathrm{E}\right.$ ) is only $3,76 \%$ (Figure $3(\mathrm{~b})$ ), implying these are the least frequent fractures.

\subsubsection{Fracture Geometry and Motions}

Extension is associated with all the six fracture sets and is expressed either as a dip-slip or as an opening along fractures (Figures 4(a)-4(d) and Figures 5(a)-5(d)). Open fractures are young, with an aperture up to $3 \mathrm{~m}$ at the surface. The dip-slips are $0,5 \mathrm{~m}$ to maximum $5 \mathrm{~m}$ in the $2400 \mathrm{yr}$ PB lava, $5-20 \mathrm{~m}$ in the postglacial lavas, and up to $200 \mathrm{~m}$ in the bedrock. The N-S (N01 $\left.{ }^{\circ}-\mathrm{N} 20^{\circ} \mathrm{E}\right)$, NW $\left(\mathrm{N} 131^{\circ}-\mathrm{N} 160^{\circ} \mathrm{E}\right)$ and $\mathrm{E}-\mathrm{W}\left(\mathrm{N} 81^{\circ}-\mathrm{N} 100^{\circ} \mathrm{E}\right)$ faults have the highest dip-slips in the bedrock, judging from the visual inspection of fault scarps on aerial images and the estimated values of topographic contours on maps.

Fracture geometry is a key for identifying the strike-slip component of fractures on images (Figure 5 and Figure 6) and the en échelon segmentation in particular is the criterion for determining the sense of shear motions. Left-stepping en échelon arrays, typical of dextral motion, were observed along the WNW $\left(\mathrm{N} 101^{\circ}-\mathrm{N} 130^{\circ} \mathrm{E}\right)$ (Figure 5(a) and Figure 6(a)) and NW sets (Figure 5(b)) and Figure 6(a)), which are respectively parallel to the HFF and the Tjarnarás Fault. Right-stepping en échelon arrangements, typical of sinistral motion, appear along the NNE $\left(\mathrm{N} 21^{\circ}-\mathrm{N} 50^{\circ} \mathrm{E}\right)$ to $\mathrm{ENE}\left(\mathrm{N} 51^{\circ}-\mathrm{N} 80^{\circ} \mathrm{E}\right)$ fractures (Figures 5(c)-(d) and Figure 6(a)). The horizontal offsets of strike-slip faults are difficult to estimate due to lack of marker horizons but they are far less than the dip-slips. Data from SISZ indicate that offsets of strike-slip source faults are of the order of 
$2 \mathrm{~m}$ during a single earthquake [100], but they can be cumulative up to $20 \mathrm{~m}$ in the older bedrock such as in west Iceland [101] [102]. However, no shear motion could be identified for E-W fractures on the basis of fracture geometry. Similarly, about $7,9 \%$ of the fracture population form a NNW set $\left(\mathrm{N} 161^{\circ}-\mathrm{N} 180^{\circ} \mathrm{E}\right)$, which has a dip-slip but a strike-slip could not be identified on them either.

The en échelon segments can be the surface expression of deeper and blind strike-slip faults that have not yet broken the surface (Figure 6(c)). The best examples are the WNW and NW open fractures of Sæluhúsveggur and Grísatungur that crop out locally on the trace of the HFF (Figure 5(a)-(b)).

"V" shape fault termination is another example of fracture geometry. Shorter segments branching out towards the end of particularly individual strike-slip faults form an angle with the main fault plane. Such structures are secondary horsetail splays, accommodating the shear motion of the main strike-slip fault segment (Figure 6(c)).

Regardless of the relative age or type of fractures in Theistareykir, individual segments of a single structure can dip to opposite directions along the overall fault trace due to the steepness of the fracture planes. This feature is also observed in other areas of Iceland [25] [26].

\subsection{Interpretation of the Structural Pattern}

\subsubsection{The Fracture Sets}

The emerging structural pattern is a combination of pure extensional fractures parallel to the rift and five Riedel shear sets belonging to the transform zone (Figure 6(b)). The rift-parallel fractures are N-S, with strike-ranges identical to those on Figure 3(b). Shear motions identified from fracture geometry indicate that NNE to ENE Riedel shears act as sinistral oblique-slips, and the WNW to NW fractures display dextral motion. Although fracture geometry was not conclusive for the sense of shear motion along the E-W set, these fractures have likely a strike-slip component (either sinistral or dextral), similar to the adjacent NNE-ENE or WNW-NW sets.

The strike and motions identified here are identical to those of regional earthquakes within the TFZ [59] [60], or even to those recorded during local earthquakes above the Theistareykir geothermal field [83] [103] [104].

The stress map of Iceland combining focal mechanisms, boreholes breakouts, induced fractures, and geological features [65] shows that stress fluctuations occur both in and adjacent to the rift and transform plate boundaries. Such fluctuations result in the co-existence of normal faults and a wide range of strike-slips, regionally. Detailed stress analyses in this part of TFZ and NRZ [63] indicate that the spreading direction is roughly $\mathrm{N} 102^{\circ} \mathrm{E}$ near the $\mathrm{NRZ}$, but $\sim \mathrm{N} 80^{\circ} \mathrm{E}$ across $\mathrm{TFZ}$, thus splitting the displacements into transversal (dip-slip motion) and lateral (strike-slip motion). Thorough analysis of kinematic indicators in the bedrock between the HFF and the DL identified severe fluctuations in the direction of $\mathrm{S}_{H \max }$ which explains strike- and dip-slip motions on a wide range of fractures [64].

Although detailed stress analysis has not been carried out for any rock age in 
Theistareykir, the tectonic context, rock ages, and fracture sets are identical to those studied by [63] [64] [65]. Therefore, similar complex stress fluctuations can be expected in Theistareykir as well, explaining why extension is associated with fractures of all sets and why strike-slip occurs on such a wide strike-range in rocks of any age.

\subsubsection{The Structural Weak Zones}

An attempt was made to identify the structural weak zones in the study area [14]. These zones are defined here based on one or several of the following criteria on aerial images: zones with high fracture density, prominent morphostructural geometries in the landscape, pronounced displacements, and control of lava structures (Figure 6(d)). As these zones form along any set, identifying them is critical for a better understanding of the tectonics of rift and transform zones and for their roles in the control of geothermal activity.

These structural weak zones display various configurations, regardless of whether they have broken the surface and been reactivated, or they are only surface expressions of deeper blind faults. The weak zones that have broken the surface appear as one dominant structure, or as a cluster of segments having more or less sharp traces and variable amount of dip-slips. The deep structures that did not break the surface consist mostly of minor or faint segments, open fractures, and occasionally of major segments along the fracture trace. Although the strike-range of fracture segments within a structural weak zone can be wide (Figures 3(b)) and Figure 6(b)), the strikes and motions of those individual segments are compatible with the outline and motion of the main structural weak zone. Several interesting features appear from the interpretation of these zones, some of which are shown for the first time by this study:

a) The weak zones belonging to the rift and transform zones appear tightly parallel and widely distributed throughout the Theistareykir Fissure Swarm. Together, they form a complex fracture pattern (Figure 7(a)), responsible for block compartmentalization at any scale. Along their lengths on aerial images, these weak zones cut the series of all ages at the surface (Figure 2), while well data (ÍSOR database) indicate highly fractured bedrock also under the thin postglacial and the $2400 \mathrm{yr}$ BP lavas in Theistareykir. Most of the subtle structures in the younger lavas are likely reactivation of older underlying structures.

b) The Theistareykir Fissure Swarm is interpreted here as having an $11 \mathrm{~km}$ width (Figure 2 and Figure 7). This suggestion is based on the observation that the western boundary of this swarm could be on the trace of the last N-S postglacial eruptive cone and the northward continuation of the N-S normal fault segment to the north of Skessuskál, while its eastern boundary could be the N-S structure stretching from Ketilfjall southwards on the trace of the last open fractures at Kvíhólafjöll.

c) The N-S rift-parallel fractures are the most frequent individual set. However, they do not display a high number of weak zones compared to the other sets of the study area (Figure 3(b) and Figure 7(a)). Most N-S weak zones consist of 
young open fractures in the postglacial lavas, and of normal faults with conspicuous dip-slips ( $\geq 200 \mathrm{~m}$ ) in the bedrock. From the HFF to the south, two short grabens occupy the central part of this fissure swarm (Figure $7(\mathrm{~b})$ ). The graben to the north cuts the $2400 \mathrm{yr} \mathrm{BP}$ lava, and the one to the south the postglacial lavas of Borgarhraun and the subglacial hyaloclastites of Bæjarfjall. Almost all the $\mathrm{N}-\mathrm{S}$ weak zones are on the flanks of these two grabens, i.e., away from the centre of the fissure swarm (Figures 7(a)-(b)).

Although smaller horsts and grabens exist on the flanks of each graben, generally, N-S faults dip mostly to the west on the eastern flanks of the grabens, and to the east on their western flanks.

d) An interesting relation may exist between the NNE and ENE structural weak zones. Open fractures strike far more NNE than ENE (Figure 2 and Figures 5(c)-(d)). Similar to the WNW and NW dextral open fractures in Sæluhúsveggur/Grísatungur, the en échelon NNE sinistral fractures appear very near or above the ENE structures (Figures 5(a)-(d)), thus acting possibly as surface expressions of deeper ENE strike-slip faults.

e) Although E-W structures are the least common, the dip-slip of a few older E-W faults in the bedrock to the west of Skeiðin is among the highest observed. Both the dip-slips and the traces of those E-W faults decrease drastically in the adjacent younger lavas.

f) The WNW weak zones are as frequent as the N-S zones (Figure 7(a)). WNW faults generally dip to the southwest and display both dip-slip and dextral motion similar to the HFF. For the record, the WNW segments of the HFF $\left(\mathrm{N} 121^{\circ}-\mathrm{N} 130^{\circ} \mathrm{E}\right)$ are relatively straight, identical to all other WNW structures of similar strikes (Figure 2).

g) The NW weak zones contain faults and fractures that dip mostly to the southwest. These structures display some of the highest dip-slips in the bedrock, and the highest number of open fractures after the N-S set. The Tjarnarás Fault and the open fractures of Grísatungur are the most obvious NW structures (Figure 5(b)). Two hypotheses are suggested for at least these latter NW open fractures. First, their typical en échelon geometry could correspond to a local reopening of several parallel NW faults of the bedrock that intersect the HFF. Such an opening is along the NE direction and almost perpendicular to the WNW direction of spreading. Secondly, these NW en échelon open fractures could be short dextral segments that accommodate the shear motion of the HFF at the surface together with the neighbouring WNW open fractures of Sæluhúsveggur. Neither these open fractures nor the Tjarnarás Fault are the sole NW structures in the area as NW weak zones are widely spread, with a subtle left-stepping en échelon arrangement indicative of a dextral motion.

\subsubsection{Eruption through a Strike-Slip Fault}

Due to their significance for the eruption and geothermal activity, some specific features of the N-S and WNW structures are further interpreted here.

As stated earlier, very few N-S dykes, and none with other strikes, crop out in 
the study area due to the level of erosion. N-S eruptive fissures typical of rift fissure swarms in north Iceland are not common here either. Furthermore, the two $\mathrm{N}-\mathrm{S}$ grabens in the middle of the Theistareykir Fissure Swarm seem to be shifted in an apparent sinistral motion [51] [92] at the latitude of Stórihver (Figure 7 (b)). Based on the number of N-S faults on the grabens' flanks, fault geometry and geological elements at Stórihver, a new structural analysis [105] suggests that the N-S grabens are shifted by the dextral motion of a WNW strike-slip fault crossing the Stórihver crater, and that the $2400 \mathrm{yr}$ BP eruption of the picrite lava likely occurred on this deep and mostly blind fault of the transform zone. A short horsetail splay of the main WNW fault, also with a dextral oblique-slip motion, stretches from north and east of Stórihver eastward into the geothermal field.

The eruption on a WNW fault perpendicular to the Theistareykir rift fissure swarm demonstrates that strike-slip faults are pathways for magma, and that transform zones can be leaky. Magma injection into strike-slip faults of transform segments is not so uncommon as it is reported from the Tertiary dykes of west Iceland [106], the TFZ in north Iceland [42], the young eruptive fissures in the RP oblique rift in southwest Iceland [107], and even the 2014 fissure eruption of Holuhraun stretching from Bárðarbunga to the north of Vatnajökull [44].

\subsubsection{Fracture Formation and Evolution}

The mapped fractures are of different ages and at different stages of evolution during which they coalesced, accumulated slip, and were reactivated. As the N-S extensional faults parallel to the rift constitute only $16,6 \%$ of the fracture population (Figure 3(b)), a rough insight into how the fractures form and evolve is crucial particularly where rift and transform zones interact.

An absolute dating of these fractures requires other data than available in this paper. Therefore, a simple method is used here where the 10729 fracture segments are classified in three main groups according to the relative age of their host rocks (Figures 8(a)-(d)), using the method of fracture-strike vs. fracture-length [99]. This approach may be simplistic, because young fractures can also form in the older series. Yet, it provides an overall understanding of how the extensional fractures of the rift and the Riedel shears of the transform zone form and evolve in time [15]. The strike-ranges of the sets described below correspond to fractures for which pure extension and shear motions could be identified.

a) Group (1) represents the youngest fractures, as they are in the $2400 \mathrm{yr} \mathrm{BP}$ Theistareykir lava (Figure $8(\mathrm{~b})$ ). It is reiterated that fractures in this lava have generally minor or faint traces as they are still young and not fully developed. Clockwise, their frequency is: N-S (9,5\%), NNE (12,6\%), ENE (21,4\%), E-W $(7,7 \%)$, WNW (24,4\%) and NW (17,8\%). At this stage, the WNW, ENE and NW sets are the most widespread, while the N-S, NNE, and E-W sets are the least common.

b) Group (2) consists of fractures cutting the postglacial lavas $(15,000-8000$ yrs) that surround the young Theistareykir lava (Figure $8(c)$ ). Their frequency is: N-S (17,2\%), NNE (14\%), ENE (17,2\%), E-W (6,1\%), WNW (18,6\%) and NW 
$(18,5 \%)$. At this stage in time, the percentage of N-S fractures has increased drastically, and along with the WNW, NW and ENE sets, they form the four most prominent fracture sets.

c) Group (3) corresponds to fractures mapped in the older series, i.e., Quaternary to upper Tertiary lavas and hyaloclastites (Figure 8(d)). In general, faults in these rocks are the oldest, and the percentage of fresh structures or young open fractures is not high. At this stage, the fracture frequency remains almost the same as in Group (2), with N-S (17,7\%), NNE (13,2\%), ENE (17,3\%), E-W (6,7\%), WNW (17\%) and NW (19,2\%).

This analysis shows two important features. First, the WNW to NW dextral and ENE sinistral strike-slip faults dominate Group (1), and the N-S faults double in the older Groups (2) and (3). This implies that young fractures form under the influence of the transform zone, and only with time the effect of rifting becomes significant. Secondly, regardless of age, the Riedel shears of the transform zone are more widespread than the extensional fractures of the rift.

\subsection{Correlation with Other Surface and Subsurface Data}

\subsubsection{Surface Manifestations}

Surface manifestations consist of soil modified to clay, as well as mineral deposition, all caused by hot water and steam in fumaroles, solfataras, steam vents, mud pools and springs. However, alteration can also be hidden below the soil due to circulation of hot water that has not yet reached the surface. Surface mapping from aerial images [14] (Figure 9(a)) and outcrops [51] [88] [96] [108] show that alteration is localized in Theistareykir, within $4,5 \mathrm{~km}$ from the eastern boundary of this fissure swarm (Figure 7 and Figure 9(a)). Almost all fumaroles, solfataras and steam vents are located in the area of the most severe alteration (Figure 9(b)).

The boundaries of the block containing the surface alteration are suggested on Figure 9(a). The block has an overall $\mathrm{N} 15^{\circ} \mathrm{E}$ elongation. However, it presents variations along its western edge, which coincide with the structural weak zones numbered on Figure 9(c): the $\mathrm{N} 117^{\circ} \mathrm{E}$ dextral oblique-slip segment of the HFF (No. 1); the $\mathrm{N} 46^{\circ} \mathrm{E}$ oblique-slip sinistral fault to the northeast of Stórihver (No. 2) and the westernmost $\mathrm{N} 162^{\circ} \mathrm{E}$ segment of the Tjarnarás dextral oblique-slip fault (No. 3); two $\mathrm{N} 15^{\circ} \mathrm{E}$ normal faults (No. 4) and a short $\mathrm{N} 135^{\circ} \mathrm{E}$ dextral strike-slip segment (No. 3) to the west/southwest of the block. Finally, the outer edge of the block to the east could be the last N-S structure stretching from Kvíhólafjöll northwards to Ketilfjall (No. 4).

The same fracture sets of rift and transform zones seem to control the configuration of alteration within the block. Parallel ENE fractures (No. 2b) dominantly control the alteration in the centre of the block. This central zone is also bounded by other WNW (No. 1b), NW (No. 3a) and NNE (No. 2c) segments, and it contains the WNW dextral strike-slip horsetail splay of the Stórihver Fault (No. 1c) in presence of a short N-S fault (No. $4 b$ ). The narrower alteration zones to the south of the block could be controlled by N-S (No. 4c) and NW (No. 3c) 
fractures, while the isolated possible alterations to the north could be aligned on other ENE and WNW segments (No. 1a and 2a). The majority of the fumaroles, solfataras and steam vents appear aligned on these sets and even the same structures as controlling the alteration (Figure 9(d)).

Evidence of upflow and well data support the existence of the "alteration block" and the dominant role of the Riedel shears in geothermal activity:

a) The hottest of the drilled wells, with boiling temperature of $300^{\circ} \mathrm{C}$ at 1100 $m$ depth (ÍSOR database) are all within the ENE zone in the centre of the "alteration block". Even outside this block, the ENE structures play a role in deep fluid flow.

In a well drilled at Stórihver (PG-8), the N-S faults are dominant down to $1700 \mathrm{~m}$ but total circulation loss is associated with ENE fractures between 1700 $\mathrm{m}$ and $1770 \mathrm{~m}$ [109], which is also identified from the surface in this study (No. 5 on Figure 9(c)).

b) In an isolated site west of the "alteration block", steam $\left(40^{\circ} \mathrm{C}-82^{\circ} \mathrm{C}\right)$ escapes from the lava along a short NW line to the south of Stórihver (No. 1 on Figure 9(d)). As surface measurements did not reveal H2S there [51], the steam is likely from shallow ground water [88] [96] heated by vapor emanating from the geothermal reservoir. The possible structural paths of the vapor from the reservoir could be successively from the western NNE and N-S boundaries of the "alteration block" (No. 2a and 4 on Figure 9(c)), the WNW Stórihver Fault and then the NW fractures. In winter, snow melts exactly along these NNE, NS and NW patches [51].

c) Temperature logs of PG-8 indicate an outflow from the main reservoir into the west of the "alteration block". The water is $200^{\circ} \mathrm{C}$ at $250-500 \mathrm{~m}(\mathrm{MD})$ depth in the well, but below that, the formation temperatures decrease to $100^{\circ} \mathrm{C}$ at $2500 \mathrm{~m}$ depth, implying a deep influx of colder water [110]. The structural path for this shallow westward outflow from the reservoir could be the splay of the Stórihver Fault (Figure 9(d)).

\subsubsection{Structural Paths of Deep Gases}

Gas monitoring in Theistareykir geothermal field has been ongoing for more than half a century [51] [90] [96] [111]. One of the monitorings used a sufficient number of measurement points and provided both maps of gas concentrations and an assessment of reservoir temperature [51]. The chemical components determined are $\mathrm{CO}_{2}, \mathrm{H}_{2}, \mathrm{H}_{2} \mathrm{~S}, \mathrm{CH}_{4}, \mathrm{Cl}, \mathrm{Rn}, \mathrm{He}$, ratio of $\mathrm{H}_{2} / \mathrm{H}_{2} \mathrm{~S}$, oxygen isotopes $\left({ }^{18} \mathrm{O} /{ }^{16} \mathrm{O}\right.$ ratio), as well as gas temperatures based on $\mathrm{CO}_{2}$ and $\mathrm{H}_{2} \mathrm{~S}$ in steam. In this study, the original determinations of $\mathrm{H}_{2} / \mathrm{H}_{2} \mathrm{~S}, \mathrm{H}_{2} \mathrm{~S}, \mathrm{CO}_{2}$, radon and two of the gas temperatures $\left(\mathrm{CO}_{2}\right.$ and $\left.\mathrm{H}_{2} \mathrm{~S}\right)$ are selected for a correlation with the structural pattern (Figures 10(a)-10(f)).

Overall, five temperature provinces are suggested based on gas geothermometry [93] [112]. The hottest area is interpreted to be to the northeast (Ketilfjall), but temperature decreases along NW parallel isolines from Ketilfjall towards Tjarnarás and Stórihver. An early attempt to interpret the structural control of 
the concentrations, ratio, and temperatures of the gases suggested that NW and ENE structures could have an influence on a couple of gases [51]. However, the structural map available for that interpretation showed a few N-S rift-parallel fractures and the NW Tjarnarás Fault as the sole structures present above the reservoir [51].

In this study, the new structural pattern of both the rift and the transform zones (Figures 10(a)-10(f)) is used to interpret the structural control and distribution of several of the gases determined in steam [15]. Although the chemical monitoring data date from long before the new structural map was prepared, the two datasets fit strikingly. They show that major changes in the concentrations of gases and their isolines display a pattern, whose orientation and location coincide with the mapped structures.

Selected examples are the ratio of $\mathrm{H}_{2} / \mathrm{H}_{2} \mathrm{~S}$, as well as the concentrations of $\mathrm{H}_{2} \mathrm{~S}$, $\mathrm{CO}_{2}, \mathrm{Rn}$, along with the gas temperatures of $\mathrm{CO}_{2}$, and $\mathrm{H}_{2} \mathrm{~S}$ (Figure 10). Their isolines show that three Riedel shear sets striking ENE, WNW and NW, along with the N-S extensional fractures control these distributions. Of these, the ENE sinistral weak zone in the centre of the "alteration block" seems to have the most dominant role, followed by the WNW dextral oblique-slip splay segment of the Stórihver.

An in-depth analysis is not at hand to determine at what depths the gases originate before reaching the surface. However, assumptions are that the gases come from a depth of 2 to $7 \mathrm{~km}$, where the $\mathrm{CO}_{2}$ and $\mathrm{H}_{2}$ are among the deepest and methane among the shallowest (Ârmannsson, Pers. Comm., 2015). Even if the fractures of rift and transform zones have mild dip-slips or even faint traces above the reservoir at the surface, the structures of both plate boundary types are pathways for the emanation of deep gases.

Although not shown here, correlations were also made between the fracture pattern and data from ten of the wells located in the core of the alteration block. The results demonstrate that the main WNW, ENE, NW and N-S fault segments also create permeability for feeders at depth [16], while the NNE Riedel shears play a lesser role and mostly as secondary fractures.

\subsubsection{Tectonic Settings of Resistivity Anomalies}

The recent resistivity survey of Theistareykir and surroundings is a 3D inversion of MT data with a high number of measurement points along N-S and E-W profiles (Figures 11(a)-11(h)). The survey provides revealing information on geothermally altered bodies (or anomalies) down to $12 \mathrm{~km}$ b.s.l. [89]. The data show a shallow cap rock down to $400-800 \mathrm{~m}$ depth, reflecting the zeolite/smectite alteration zone. An underlying high resistivity core corresponds to the chlorite/epidote alteration zone, which rises to $200 \mathrm{~m}$ b.s.l. below the Theistareykir geothermal field. Finally, a deeper low resistivity body, possibly indicative of the heat source and upflow zones of geothermal fluid into the system, appears below Ketilfjall, Bæjarfjall and north of Stórihver. Two distinct connected low resistivity bodies also exist to the northwest of the surveyed 
area (i.e., south of Sæluhúsveggur). They reach down to several kilometres b.s.l. (Figures $11(\mathrm{c})-11(\mathrm{~h})$ ), but it is unknown whether they are of alteration or magmatic origin [89].

The width of individual resistivity anomalies can be from $<1 \mathrm{~km}$ to $\geq 4 \mathrm{~km}$. A clarification regarding these widths is necessary before interpreting their structural control. In this study, the resistivity anomalies are interpreted as being bounded by a series of fractures (narrow weak zones) along a given set and not controlled by single fractures. This interpretation stems from observations of numerous altered fault zones in the $1,5 \mathrm{~km}$ eroded upper Tertiary crust of west Iceland [25] [106], the 0,7 km eroded Hreppar micro-plate of south Iceland [26], and the $>2 \mathrm{~km}$ eroded series of the Asal Rift in Djibouti [20].

In those outcrops, alteration is mostly associated with fault zones of oblique-slip faults where the width of the altered zone ranges from $10 \mathrm{~m}$ to $50 \mathrm{~m}$ along a single fault. It is, therefore, unlikely that the width of the resistivity anomalies in Theistareykir results from fluid flow along a single permeable fracture in the middle of each body.

In the initial investigation [15], the tectonic settings of the resistivity anomalies were interpreted at depth intervals of $0 \mathrm{~m}, 500 \mathrm{~m}, 1000 \mathrm{~m}, 1500 \mathrm{~m}, 2000 \mathrm{~m}$, $2500 \mathrm{~m}, 3000 \mathrm{~m}, 4000 \mathrm{~m}, 5000 \mathrm{~m}, 6000 \mathrm{~m}$ and $8000 \mathrm{~m}$ b.s.l. by superimposing them on the structural map. Due to similarities of the structural settings, only the depth intervals with significant differences are presented here for discussion (Figures 11(c)-11(h)). Their main interpretations are:

a) Resistivity anomalies display strong left- and right-stepping en échelon arrangements, typical of dextral and sinistral structures and the boundaries of these anomalies coincide with individual structural weak zones.

b) From 0 to $4000 \mathrm{~m}$ b.s.l., the resistivity anomalies are controlled by the WNW and NW dextral oblique-slip, and by the NNE to ENE sinistral oblique-slip Riedel shears. The ENE set, however, appears as a clear and dominant set mostly from depths of 2500 to $4000 \mathrm{~m}$ b.s.l. (Figure 11(e) and Figure 11(f)). Two WNW segments including the HFF form a deformation zone to the west. In this WNW zone, shorter N-S resistivity anomalies are bounded by rift-parallel structures, much like extensional pull-aparts within Riedel shear zones (Figures 11(c)-11(f)). From $5000 \mathrm{~m}$ b.s.l., the E-W set becomes more established. Along with the NW, WNW and the ENE sets, the E-W set controls a major anomaly to the east of the study area (Figures 11(g)-11(h)). At $8000 \mathrm{~m}$ b.s.l., the E-W and $\mathrm{N}-\mathrm{S}$ sets are dominant. The N-S set is confined to the west of the study area, and a few NW structures still bound the deepest resistivity anomalies to the east (Figure 11(h)). It is noteworthy that on maps, the resistivity anomaly below the geothermal area appears clearly only from $2000 \mathrm{~m}$ b.s.l., and it is controlled by the Riedel shears down to $8000 \mathrm{~m}$ b.s.l. (Figures 11(d)-11(h)).

c) The resistivity anomalies and the structural weak zones controlling them present a gradual clockwise rotation of up to $42^{\circ}$ to the east between $0 \mathrm{~m}$ and $4000 \mathrm{~m}$ b.s.l. The most obvious changes take place between $1000 \mathrm{~m}$ to $4000 \mathrm{~m}$ 
b.s.l. The WNW lineament rotate to NW/NNW by $42^{\circ}$ (median from $\mathrm{N} 118^{\circ} \mathrm{E}$ to $\mathrm{N} 160^{\circ} \mathrm{E}$ ), the NNE structures to ENE by $41^{\circ}$ (median from $\mathrm{N} 23^{\circ} \mathrm{E}$ to $\mathrm{N} 64^{\circ} \mathrm{E}$ ), and the N-S structures only by $7^{\circ}$ (median from N09 ${ }^{\circ} \mathrm{E}$ to $\mathrm{N} 16^{\circ} \mathrm{E}$ ) (Figures 11(c)-11(f)). Compared to the strike ranges at $4000 \mathrm{~m}$ depth, an anticlock rotation of the structures occurs by $4^{\circ}$ to $20^{\circ}$ to the west at 5000 and $6000 \mathrm{~m} \mathrm{b.s.l}$. intervals. Thus the NNW/NW structures rotate to WNW by $20^{\circ}$ west (median from $\mathrm{N} 160^{\circ} \mathrm{E}$ to $\mathrm{N} 140^{\circ} \mathrm{E}$ ), the ENE structures rotate $14^{\circ}$ west (median from $\mathrm{N} 64^{\circ} \mathrm{E}$ to $\mathrm{N} 50^{\circ} \mathrm{E}$ ), and the $\mathrm{N}-\mathrm{S} 18^{\circ}$ west (median from $\mathrm{N} 16^{\circ} \mathrm{E}$ to $\mathrm{N} 178^{\circ} \mathrm{E}$ ). The NNE structures are rare and short, and they rotate only $4^{\circ}$ west (median from $\mathrm{N} 35^{\circ} \mathrm{E}$ to $\mathrm{N} 31^{\circ} \mathrm{E}$ ) within the depth interval of 5000 to $6000 \mathrm{~m}$ b.s.l. A couple of $\mathrm{E}-\mathrm{W}$ structures $\left(\mathrm{N} 83^{\circ} \mathrm{E}\right.$ and $\left.\mathrm{N} 86^{\circ} \mathrm{E}\right)$ bound a major resistivity anomaly to the east of the area. They are a part of an ENE structural zone at $4000 \mathrm{~m}$ b.s.l., but at $5000 \mathrm{~m}$ b.s.l., their eastern half rotates clockwise after intersecting a NW structural zone (Figure 11(g)). At $8000 \mathrm{~m}$ b.s.l., the structures present again a clockwise rotation of $3^{\circ}$ to $14^{\circ}$ compared to the strike ranges at $6000 \mathrm{~m}$ b.s.l. At the great depth of $8000 \mathrm{~m}$, the deep E-W structure has rotated only $3^{\circ}$ to the east (median from $\mathrm{N} 86^{\circ} \mathrm{E}$ to $\mathrm{N} 89^{\circ} \mathrm{E}$ ), the $\mathrm{N}-\mathrm{S}$ structure $5^{\circ}$ (from $\mathrm{N} 178^{\circ} \mathrm{E}$ to $\mathrm{N} 03^{\circ} \mathrm{E}$ ), and the NW set $14^{\circ}$ to (median from N140 $\mathrm{E}$ to $\mathrm{N} 154^{\circ} \mathrm{E}$ ) (Figure $11(\mathrm{~h})$ ).

The above interpretation reflects the dominance of the Riedel shears of the transform zone in the alteration process down to $8 \mathrm{~km}$ depth in the crust, as well as the concept of rotation of the structures. These rotations are summarized on Figures 13(a)-13(c), along with the strike-ranges of the most common structures at each depth interval (Figure 13(d)).

\subsubsection{Dominant Structures in Relation to Earthquakes}

Figure 12(a) shows the structural weak zones identified regionally, and highlights the interpreted structures controlling the geothermal activity. Two sets of relocated earthquakes from 1993-2011 [83] and 2014-2015 [104] are interpreted in the light of this tectonic setting.

a) The 1993-2011 earthquakes (SIL network) to the west and northwest of Bæjarfjall are with magnitudes of $-0,6 \leq M_{1} \leq 3,2$ and a depth range of 3 to $7 \mathrm{~km}$. They are grouped into four clusters and interpreted with complex alternative fault motions in each cluster [83]. These clusters are numbered as 1 to 4 on Figure 12(b) where the structural pattern obtained in this study is used as a basis to evaluate which of the alternative fault motions suggested by [83] are most likely. This study interprets the fault motions as follows: In clusters 1 and 2 (Figure 12(b)), the fault plane solutions (FPS) for the NW Tjarnarás Fault and the WNW Stórihver Faults are dextral oblique-slip on both structures. The group of earthquakes on the western slope of Bæjarfjall (No. 3 on Figure 12(b)) coincides with the NNE segments identified there as having a sinistral oblique-slip motion. The cluster of earthquakes distributed to the north of Bæjarfjall (No. 4 on Figure 12(b)) likely aligns on the ENE sinistral oblique-slip weak zone identified there [14].

b) The 2014-2015 earthquakes are mostly located under the top of Bæjarfjall and to a lesser degree to its northwest (SIL and Landsvirkjun-ÍSOR network) 
(Figures 12(a)-12(b)). Their magnitude is 1 to $1,9 \mathrm{M}_{1}$ and their depth 2 to $4 \mathrm{~km}$, although some reach down to $6 \mathrm{~km}$ depth [104]. The seismic lineations of these earthquakes likely fall on parallel ENE sinistral oblique-slip segments that form the southern boundary of the main ENE zone within the alteration block [17] (Figure 12(a)). Some of the seismic lineations in Bæjarfjall could also align on tightly parallel WNW segments associated with the Stórihver Fault there [17] (Figure 12(b)). Three of the six available FPS for these earthquakes [104] indicate a dextral oblique-slip on the WNW segment of the Storihver Fault that cut the main crater of Bæjarfjall (Figure 12(a)). The fit between the hypocentres of these earthquakes [104] and the structures mapped from the surface stems from the fact that ruptures occur on steeply-dipping fractures (i.e., $\geq 75^{\circ}$ from horizontal).

Finally, some of the 2014-2015 earthquake activity in Bæjarfjall has been attributed to the discharge of geothermal wells [17] [104] [113]. Even though these are "triggered" or "induced" earthquakes, they still indicate fault slips on existing fractures, most of which are mapped in this study.

\section{Conclusions and Discussions}

As a part of geothermal exploration for drilling, this multidisciplinary structural analysis evaluated the tectonic pattern of the Theistareykir Fissure Swarm over an area of $165 \mathrm{~km}^{2}$ at the intersection of the Northern Rift Zone (NRZ) and the Tjörnes Fracture Zone (TFZ). The structures were extracted from several types of aerial images and hillshade (Figure 1, Figure 2). The fracture sets, geometry and motions, spatial distribution (Figures 4-7), frequency (Figure 3) and relative fracture evolution in time (Figure 8) were assessed. The structural pattern obtained was then correlated with surface geothermal manifestations (Figure 9), emanating gases (Figure 10), resistivity (Figure 11) and local earthquakes (Figure 12(a)) to identify the structures responsible for geothermal activity. The results provide a comprehensive tectonic setting of rift and transform zones within the NRZ and the TFZ onland, an interpretation of the critical structures at surface and depth (Figure 13), and a conceptual model of the Theistareykir fractured geothermal reservoir. Below are selected key findings and discussions.

\subsection{Main Conclusions}

The mapped structures are segmented faults, open fractures and prominent joints, with lengths varying between $0,5 \mathrm{~m}$ and $5000 \mathrm{~m}$. Fracture traces are more prominent in the upper Miocene-Pleistocene rocks and less in the postglacial/Holocene lavas. The structural analysis of the fractures and correlation with selected surface and subsurface data show:

- The structural pattern consists of six sets, i.e., the N-S extensional rift fractures, and the Riedel shears of the transform zone striking WNW to NW (dextral), NNE to ENE (sinistral). Shear motion could not be identified on E-W and NNW sets, but the E-W fractures have likely a strike-slip component.

- Extension is associated with all sets and expressed as dip-slip $(<1-200 \mathrm{~m})$ or open fractures $(\leq 3 \mathrm{~m})$. The N-S, E-W, NW faults, and the WNW segments of 
the HFF have the highest dip-slips in the bedrock, while open fractures strike dominantly N-S, NW and NNE.

- The magnitudes of horizontal offsets are unknown due to lack of marker horizons. However, horsetail splays at an angle with the main structures (e.g., the WNW Stórihver Fault-StF) accommodate the shear motion of the main fault over a larger area.

- The Riedel shears dominate in the $2400 \mathrm{yr}$ BP lava with the WNW fractures (24,4\%), ENE (21,4\%), NW (17,8\%), NNE (12,6\%) and E-W (7,7\%). Only 9,5\% of the fractures strike N-S. The Riedel shears also prevail in older rocks although the N-S fractures almost double in postglacial $(17,2 \%)$ and late Quaternary-upper Tertiary series (17,7\%). Fractures form dominantly under the influence of the transform mechanism, and the effect of rifting becomes apparent only with time.

- Any set displays structural weak zones at the surface, expressed as areas of high fracture density, en échelon arrays above deeper structures, or major individual structures indicative of fault reactivation.

- The regularly spaced weak zones of the six sets form a complex fracture pattern, compartmentalizing the blocks at any scale. The N-S weak zones, however, are concentrated on the flanks of the two central grabens, accommodating the stretching caused by the dextral motion of the magmatically leaky WNW StF.

- WNW, ENE, NW, N-S and NNE structural weak zones control the block hosting the surface alteration, the alignment of geothermal manifestations, the distribution of deep gases, and they also rupture during natural or induced earthquakes. The WNW dextral StF and its splay, the ENE sinistral fault to the north of Bæjarfjall, the NW Tjarnarás Fault, and a few N-S faults are some of those critical structures.

- Resistivity anomalies display typical left- and right-stepping en échelon arrangements and are controlled by the same sets of rift and transform zone fractures. These anomalies present clockwise and anticlockwise rotations down to 8 $\mathrm{km}$ crustal depth, reflecting the dominant fracture sets of each depth-interval. At $8 \mathrm{~km}$ depth, the N-S rift structures as well as the E-W and the NW Riedel shears dominate the root of the rift and transform plate boundaries.

\subsection{Discussions}

With a spreading direction at $\mathrm{N} 105^{\circ} \mathrm{E}$ [68], the N-S extensional fractures are expected to dominate the structural pattern. In fact, the focus of most previous geological mappings in the Theistareykir Fissure Swarm [50] [51] [55] [92] [95], and the NRZ [56] was on these extensional fractures, and to a lesser degree on the transform zone structures [24] [51] [53], up to recently [14] [16] [66]. Such an emphasis resulted in interpreting even some of the fracture sets as sinuosity of rift-parallel structures [54] [55] [95], or attributing the geothermal activity to rift structures [51] [95].

Part of the findings in this study is in good agreement with previous works. But as some of the findings are presented for the first time in this area, or are 
different from previous interpretations, a short discussion is necessary.

- The six fracture sets identified here are a combination of rift extensional fractures and the Riedel shears of the transform zones, where the Riedel shears dominantly control the tectonic processes at surface, depth, and in time. Even if fractures are subtle in the young lavas of Theistareykir, the existence of the identified sets and even some of the fractures is demonstrated by present-day regional earthquakes [59] [60] [81]. Furthermore, a similar structural pattern crops out widely in the bedrock to the west of the study area where complex stress evolution/fluctuations have been identified over longer geological time scales [64]. Therefore, the suggested pattern is likely present also at depth under the young lavas of Theistareykir.

- Bookshelf tectonic has been reported between two of the fissure swarms of the NRZ at some $150 \mathrm{~km}$ southeast of the present study area [114]. However, the suggested structural pattern in Theistareykir is within a single rift fissure swarm and does not reflect such a deformation.

- The low frequency of rift-parallel fractures compared to the Riedel shears is not an isolated occurrence in NRZ and TFZ. This is a common feature to all areas where rift and transform zones interact, regardless of the age of the plate boundaries, such as in west [25], south Iceland [26], [115], and southwest Iceland [107].

- The structural map in this study benefits from a variety of images including stereo aerial photographs, a range of resolutions $(0,5$ to $2,5 \mathrm{~m}$ per pixel on the ground), and intensive experience in outcrop mapping of young and older structures in Iceland. Therefore, some of the results are different from those of previous investigations. For example, in this study the majority of the N-S faults is interpreted as dipping westward on the eastern flank of the two N-S central grabens in the Theistareykir Fissure Swarm, and eastward on their western flanks. Although this observation differs from that of [55], it is a typical structural configuration associated with grabens worldwide.

- Young WNW and NW left-stepping en échelon segments can act as surface expressions of deeper strike-slip faults, or as splays of each other [14] [15] [16]. These structures of the Theistareykir area were interpreted in the same manner also by [66]. The NW fractures are, however, too widespread regionally to be only secondary fractures adjusting the shear motion of deeper WNW structures. Therefore, in addition to the above interpretation, in the present study the NW fractures are considered to be an individual set as also supported by fault ruptures during natural earthquakes [83]. The NW set both strikes and has a dextral component, similar to GOR offshore.

- Some of the results obtained in this study confirm less common processes such as magma injection into strike-slip faults [44] [106] [116] , and the fact that transform segments can be magmatically leaky in Iceland [42] [105].

- Finally, the rotation of the resistivity anomalies at depth, and the fracture sets bounding them (Figure 13), are dominantly controlled by the Riedel shears in the upper $6 \mathrm{~km}$ in the crust. Both the dominance of the Riedel shears and the 
rotations of the structures with depth are new concepts for Iceland, with relevance to structural drilling targets. Although more analysis and modeling are required, results indicate that the deepest structures at the root of the rift and the transform zones $(8 \mathrm{~km})$ are N-S, E-W and NW.

Many results of the present paper are reported for the first time and apply to a large region. Although they are a contribution towards further understanding of the tectonic of this area, additional investigations are needed to deepen the knowledge. Examples of topics to be addressed are whether the observed tectonic pattern is limited to the Theistareykir region or has an even more regional extent, or if the transform zone structures are more frequent than the rift structures everywhere within the NRZ and the TFZ.

\section{Acknowledgements}

The original geothermal exploration of Theistareykir, which main results are presented here, was commissioned over many years by the National Power Company (Landsvirkjun). The authors thank Ásgrímur Guðmundsson and Egill Júlíusson (Landsvirkjun's project managers) for permission to publish the results, as well as Anette Mortensen, the initial project manager at ÍSOR (now at Landsvirkjun). At ÍSOR, Guðrún Sigríður Jónsdóttir and Gunnlaugur Einarsson helped with the GIS, and Halldór Ármannsson provided useful comments. The authors also thank Egill Júlíusson for fruitful discussions on the tectonics of fractured reservoir, Daniele Trippanera for suggestions on an earlier version of this manuscript, two anonymous reviewers of Open Journal of Geology for relevant comments, and Joanna Cheng, the Managing Editor, for assistance.

\section{References}

[1] Barberi, F., Marinelli, G., Santacroce, R., Tazieff, H., Varet, J., Chedeville, E., Faure, H. and Giglia, G. (1973) Geology of Northern Afar (Ethiopia). Revue de Géographie Physique et de Géologie Dynamique, XV, 443-490.

[2] Group Tanganydro (1992) Les sites hydrothermaux sous-lacustres à sulfures massifs du fossé Nord-Tankanyika, Rift East-Africain: Expédition TANGANYDRO 1991. Compte Rendue Académie Sciences, Paris, 315, 733-740.

[3] Omenda, P.A. (1998) The Geology and Structural Controls of the Olkaria Geothermal System, Kenya. Geothermics, 27, 55-74. https://doi.org/10.1016/S0375-6505(97)00028-X

[4] Christiansen, R.L. (2001) Geology of Yellowstone National Park: The Quaternary and Pliocene Yellowstone Plateau Volcanic Field of Wyoming, Idaho, and Montana. U.S. Geological Survey Professional Paper, 729-G, 145 p.

[5] Faulds, J.E., Coolbaugh, M., Blewitt, G. and Henry, C.D. (2004) Why Is Nevada in Hot Water? Structural Controls and Tectonic Model of Geothermal Systems in the Northwestern Great Basin. Geothermal Resources Council Transactions, 28, 649-654.

[6] Cole, J.W. (1990) Structural Control and Origin of Volcanism in the Taupo Volcanic Zone, New Zealand. Bulletin of Volcanology, 52, 445-459. https://doi.org/10.1007/BF00268925

[7] Begg, J. and Mouslopoulou, V. (2010) Analysis of Late Holocene Faulting within an Active Rift Using Lidar, Taupo Rift, New Zealand. Journal of Volcanology and 
Geothermal Research, 190, 152-167.

https://doi.org/10.1016/j.jvolgeores.2009.06.001

[8] Wilson, C.J.N. and Rowland, J.V. (2016) The Volcanic, Magmatic and Tectonic Setting of the Taupo Volcanic Zone, New Zealand, Reviewed from a Geothermal Perspective. Geothermics, 59, 168-187.

https://doi.org/10.1016/j.geothermics.2015.06.013

[9] Curewitz, D. and Karson, J.A. (1997) Structural Settings of Hydrothermal Outflow: Fracture Permeability Maintained by Fault Propagation and Interaction. Journal of Volcanology and Geothermal Research, 79, 149-168. https://doi.org/10.1016/S0377-0273(97)00027-9

[10] Acocella, V., Korme, T., Salvini, F. and Funiciello, R. (2003) Elliptic Calderas in the Ethiopian Rift: Control of Pre-Existing Structures. Journal of Volcanology and Geothermal Research, 119, 189-203. https://doi.org/10.1016/S0377-0273(02)00342-6

[11] Meixner, J., Schill, E., Grimmer, J.C., Gaucher, E., Kohl, T. and Klingler, Ph. (2016) Structural Control of Geothermal Reservoirs in Extensional Tectonic Settings: An Example from the Upper Rhine Graben. Journal of Structural Geology, 82, 1-15. https://doi.org/10.1016/j.jsg.2015.11.003

[12] Pérez-Flores, P., Veloso, E., Cembrano, J., Sánchez-Alfaro, P., Lizama, M. and Arancibia, G. (2017) Fracture Network, Fluid Pathways and Paleostress at the Tolhuaca Geothermal Field. Journal of Structural Geology, 96, 134-148. https://doi.org/10.1016/j.jsg.2017.01.009

[13] Palgan, D., Devey, C.W. and Yeo, I.A. (2017) Volcanism and Hydrothermalism on a Hotspot-Influenced Ridge: Comparing Reykjanes Peninsula and Reykjanes Ridge, Iceland. Journal of Volcanology and Geothermal Research, 348, 62-81. https://doi.org/10.1016/j.jvolgeores.2017.10.017

[14] Khodayar, M. and Björnsson, S. (2013) Preliminary Fracture Analysis of Peistareykir Geothermal Field and Surroundings, Northern Rift Zone and Tjörnes Fracture Zone. Iceland GeoSurvey, Report ÍSOR-2013/029, 57 p, 2 maps.

[15] Khodayar, M., Björnsson, S., Karlsdóttir, R., Ágústsson, K. and Ólafsson, M. (2015a) Tectonic Control of Alteration, Gases, Resistivity, Magnetics and Gravity in Peistareykir Area. Implications for Northern Rift Zone and Tjörnes Fracture Zone. Iceland GeoSurvey, Report ÍSOR-2015/002, LV-2015-039, 59 p, 2 maps.

[16] Khodayar, M., Björnsson, S., Kristinsson, S.G., Karlsdóttir, R. and Ólafsson, M. (2015b) Multidisciplinary Structural Analysis and Drilling Targets at Peistareykir, Northern Rift Zone and Tjörnes Fracture Zone. Iceland GeoSurvey, Report ÍSOR-2015/0043, LV-2015-0135, 49 p, 1 map.

[17] Khodayar, M., Kristinsson, S.G. and Karlsdóttir, R. (2016) Structural Drilling Targets from Platforms A, B and F at Peistareykir, Northern Rift Zone and Tjörnes Fracture Zone. Iceland GeoSurvey, Report ÍSOR-2016/0030, LV-2016-0060, 24 p.

[18] Manighetti, I., Tapponnier, P., Gillot, P.Y., Jacques, E., Courtillot, V., Armijo, R., Ruegg, J.C. and King, G. (1998) Propagation of Rifting along the Arabia-Somalia Plate Boundary: Into Afar. Journal of Geophysical Research, 103, 4947-4974. https://doi.org/10.1029/97JB02758

[19] Manighetti, I., Tapponnier, P., Courtillot, V., Gruszow, S. and Gillot, P.Y. (1997) Propagation of Rifting along the Arabia-Somalia Plate Boundary: The Gulfs of Aden and Tadjoura. Journal of Geophysical Research, 102, 2681-2710. https://doi.org/10.1029/96JB01185

[20] Khodayar, M. (2008) Results of the 2007 Surface Geothermal Exploration in the Asal Rift and Transform Zones, Djibouti: Tectonics and Geothermal Manifesta- 
tions. Iceland GeoSurvey, Report ÍSOR-2008/008, 70 p.

[21] Thouin, C. and Chorowicz, J. (1993) Contrôle structural de l'hydrothermalisme associé au rifting: Le cas du basin Nord-Tanganyika, Rift East-Africain. Compte Rendue Académie Sciences, Paris, 316, 1287-1293.

[22] Chorowicz, J. (2005) The East African Rift System. Journal of African Earth Sciences, 43, 379-410. https://doi.org/10.1016/j.jafrearsci.2005.07.019

[23] Jóhannesson, H. (1980) Evolution of the Rift Zones in Western Iceland (in Icelandic with English Summary). Náttúrufræðingurinn, 50, 13-31.

[24] Mamula, N. and Voight, B. (1985) Tectonic Analysis of Lineaments near a Spreading Axis, Northeastern Iceland. Tectonophysics, 116, 63-93.

https://doi.org/10.1016/0040-1951(85)90222-7

[25] Khodayar, M., Franzson, H., Björnsson, S., Víkingsson, S. and Jónsdóttir, G.S. (2004) Tectonic Lineaments of Borgarfjörður-Hvalfjörður from Aerial Photographs, West Iceland: Preliminary Results. Iceland GeoSurvey, Report ÍSOR-2004/021, 48 p.

[26] Khodayar, M., Björnsson, S. and Franzson, H. (2011) Hvammsvirkjun, Holtavirkjun, Urriðafossvirkjun: Synthesis of 2001-2010 Geological Data from Hreppar and South Iceland Seismic Zone. Iceland GeoSurvey, Report ÍSOR-2011/032, and Landsvirkjun Report LV-2011/073, 80 p, 11 Maps.

[27] Garfunkel, Z. (1981) Internal Structure of the Dead Sea Leaky Transform (Rift) in Relation to Plate Kinematics. Tectonophysics, 80, 81-108.

https://doi.org/10.1016/0040-1951(81)90143-8

[28] Chorowicz, J. and Sorlien, C. (1992) Oblique Extensional Tectonics in the Malawi Rift, Africa. Geological Society of America Bulletin, 104, 1015-1023. https://doi.org/10.1130/0016-7606(1992)104<1015:OETITM>2.3.CO;2

[29] Hey, R., Martinez, F., Höskuldsson, Á. and Benediktsdóttir, Á. (2010) Propagating Rift Model for the V-Shaped Ridges South of Iceland. Geochemistry, Geophysics, Geosystems, 11, Q03011. https://doi.org/10.1029/2009GC002865

[30] Hey, R., Martinez, F., Höskuldsson, Á., Eason, D.E., Sleeper, J., Thordarson, S., Benediktsdóttir, Á. and Merkuryev, S. (2016) Multibeam Investigation of the Active North Atlantic Plate Boundary Reorganization Tip. Earth and Planetary Science Letters, 435, 115-123. https://doi.org/10.1016/j.epsl.2015.12.019

[31] Karson, J.A. (2017) The Iceland Plate Boundary Zone: Propagating Rifts, Migrating Transforms, and Rift-Parallel Strike-Slip Faults. Geochemistry, Geophysics, Geosystems, 18, 4043-4054. https://doi.org/10.1002/2017GC007045

[32] Aydin, A. and Nur, A. (1985) The Types and Role of Stepovers in Strike Slip Tectonics. In: Biddle, K.T. and Christie-Blick, N., Eds., Strike-Slip Deformation, Basin Formation, and Sedimentation, Vol. 37, Society of Economic Paleontologists and Mineralogists, Special Publication, 35-44. https://doi.org/10.2110/pec.85.37.0035

[33] Withjack, M.O. and Jamison, W.R. (1986) Deformation Produced by Oblique Rifting. Tectonophysics, 126, 99-124. https://doi.org/10.1016/0040-1951(86)90222-2

[34] Dauteuil, P., Huchon, P., Quemeneur, F. and Souriot, T. (2001) Propagation of an Oblique Spreading Centre: The Western Gulf of Aden. Tectonophysics, 332, 423-442. https://doi.org/10.1016/S0040-1951(00)00295-X

[35] Agostini, A., Bonini, M., Corti, G., Sani, F. and Mazzarini, F. (2011) Fault Architecture in the Main Ethiopian Rift and Comparison with Experimental Models: Implications for Rift Evolution and Nubia-Somalia Kinematics. Earth and Planetary Science Letters, 301, 479-492. https://doi.org/10.1016/j.epsl.2010.11.024

[36] Corti, G. (2009) Continental Rift Evolution: From Rift Initiation to Incipient 
Break-Up in the Main Ethiopian Rift, East Africa. Earth-Science Reviews, 96, 1-53. https://doi.org/10.1016/j.earscirev.2009.06.005

[37] Hamlin, K.A. and Prebble, W.M. (1998) Structural Setting and Geomorphic Features of the Orakeikorako Geothermal Field, Taupo Volcanic Zone: A Remote Sensing Approach. Proceedings 20 th New Zealand Geothermal Workshop, University of Auckland, 277-284.

[38] Spinks, K.D., Acocella, V., Cole, J.W. and Bassett, K.N. (2005) Structural Control of Volcanism and Caldera Development in the Transtensional Taupo Volcanic Zone, New Zealand. Journal of Volcanology and Geothermal Research, 144, 7-22. https://doi.org/10.1016/j.jvolgeores.2004.11.014

[39] Lamarche, G., Barnes, P.M. and Bull, J.M. (2006) Faulting and Extension Rate over the Last 20,000 Years in the Offshore Whakatane Graben, New Zealand Continental Shelf. Tectonics, 25, $24 \mathrm{p}$.

[40] Mouslopoulou, V., Nicol, A., Walsh, J.J., Beetham, D. and Stagpoole, V. (2008) Quaternary Temporal Stability of a Regional Strike-Slip and Rift Fault Intersection. Journal of Structural Geology, 30, 451-463. https://doi.org/10.1016/j.jsg.2007.12.005

[41] Dauteuil, P. and Brun, J.P. (1996) Deformation Partitioning in a Slow-Spreading Ridge Undergoing Oblique Extension: Mohns Ridge-Norwegian Sea. Tectonics, 15, 870-884. https://doi.org/10.1029/95TC03682

[42] Brandsdóttir, B., Riedel, C., Richter, B., Helgadóttir, G., Kjartansson, E., Detrick, R., Dahm, T., Mayer, L., Calder, B. and Driscoll, N. (2005) Multibeam Bathymetric Maps of the Kolbeinsey Ridge and Tjörnes Fracture Zone, N-Iceland. EGU General Assembly, Nice, France.

[43] Clifton, A.E. and Kattenhorn, S.A. (2006) Structural Architecture of a Highly Oblique Divergent Plate Boundary Segment. Tectonophysics, 419, 27-40.

https://doi.org/10.1016/j.tecto.2006.03.016

[44] Sigmundsson, F., Hooper, A., Hreinsdottir, S., Vogfjörð, K.S., Ófeigsson, B.G., Heimisson, E.R., Dumont, S., Parks, M., Spaans, K., Gudmundsson, G.B., Drouin, V., Arnadottir, T., Jonsdottir, K., Gudmundsson, M.T., Hognadottir, T., Fridriksdottir, H.M., Hensch, M., Einarsson, P., Magnusson, E., Samsonov, S., Brandsdottir, B., White, R.S., Agustsdottir, T., Greenfield, T., Green, R.G., Hjartardottir, A.R., Pedersen, R., Bennett, R.A., Geirsson, H., La Femina, P.C., Bjornsson, H., Palsson, F., Sturkell, E., Bean, C.J., Mollhoff, M., Braiden, A.K. and Eibl, E.P.S. (2015) Segmented Lateral Dyke Growth in a Rifting Event at Bardarbunga Volcanic System, Iceland. Nature, 517, 191-195. https://doi.org/10.1038/nature14111

[45] Ruch, J., Wang, T., Xu, W., Hensch, M. and Jónsson, S. (2016) Oblique Rift Opening Revealed by Reoccurring Magma Injection in Central Iceland. Nature Communications, 7, Article No. 12352. https://doi.org/10.1038/ncomms12352

[46] Huchon, P. and Khanbari, K. (2003) Rotation of the Syn-Rift Stress Field of the Northern Gulf of Aden Margin, Yemen. Tectonophysics, 364, 147-166. https://doi.org/10.1016/S0040-1951(03)00056-8

[47] Delvaux, D. (2001) Tectonic and Palaeostress Evolution of the Tanganyika-Rukwa-Malawi Rift Segment, East African Rift System. In: Ziegler, P.A., Cavazza, W., Robertson, A.H.F. and Crasquin-Soleau, S., Eds., Peri-Tethys Memoir 6: Peri Tethyan Rift/ Wrench Basins and Passive Margins, Vol. 186, Mémoire de la Musée National d'Histoire Naturelle, Paris, 545-567.

[48] Fournier, M., Bellahsen, N., Fabbri, O. and Gunnell, Y. (2004) Oblique Rifting and Segmentation of the NE Gulf of Aden Passive Margin. Geochemistry, Geophysics, Geosystems, 5, Q11005. https://doi.org/10.1029/2004GC000731

[49] Brune, S. and Autin, J. (2013) The Rift to Break-Up Evolution of the Gulf of Aden: 
Insights from 3D Numerical Lithospheric-Scale Modelling. Tectonophysics, 607, 65-79. https://doi.org/10.1016/j.tecto.2013.06.029

[50] Sæmundsson, K. (1974) Evolution of the Axial Rifting Zone in Northern Iceland and the Tjörnes Fracture Zone. Geological Society of America Bulletin, 85, 495-504. https://doi.org/10.1130/0016-7606(1974)85<495:EOTARZ>2.0.CO;2

[51] Gíslason, G., Johnsen, G.V., Ármannsson, H., Torfason, H. and Árnason, K. (1984) Theistareykir: Surface Exploration in the High-Temperature Field. National Energy Authority, Report OS-84089/JHD-16, 134 p, 3 maps.

[52] Jancin, M., Young, K.D. and Voight, B. (1985) Stratigraphy and K/Ar Ages across the West Flank of the Northeast Iceland Axial Rift Zone, in Relation to the $7 \mathrm{Ma}$ Volcano-Tectonic Reorganization of Iceland. Journal of Geophysical Research, 90, 9961-9985. https://doi.org/10.1029/JB090iB12p09961

[53] Young, K.D., Jancin, M., Voight, B. and Orkan, N.I. (1985) Transform Deformation of Tertiary Rocks along the Tjörnes Fracture Zone, North Central Iceland. Journal of Geophysical Research, 90, 9986-10010. https://doi.org/10.1029/JB090iB12p09986

[54] Sæmundsson, K., Hjartarson, Á., Kaldal, I., Sigurgeirsson, M.Á., Kristinsson, S.G. and Víkingsson, S. (2012a) Geological Map of Northern Volcanic Zone, Iceland. Northern Part. 1:100.000. Reykjavík, Iceland GeoSurvey and Landsvirkjun.

[55] Magnúsdóttir, S. and Brandsdóttir, B. (2011) Tectonics of the Theistareykir Fissure Swarm. Jökull, 61, 65-79.

[56] Hjartardóttir, Á.R., Einarsson, P., Magnúsdóttir, S., Björnsdóttir, p. and Brandsdóttir, B. (2016) Fracture Systems of the Northern Volcanic Rift Zone, Iceland-An Onshore Part of the Mid-Atlantic Plate Boundary. In: Wright, T.J., Ayele, A., Ferguson, D.J., Kidane, T. and Vye-Brown, C., Eds., Magmatic Rifting and Active Volcanism, Vol. 420, Geological Society, London, Special Publications, 297-314. (First published online January 2015)

[57] Geirsson, H., Árnadóttir, Th., Hreinsdóttir, S., Decriem, J., LaFemina, P.C., Jónsson, S., Bennett, R.A., Metzger, S., Holland, A., Sturkell, E., Villemin, Th., Völksen, Ch., Sigmundsson, F., Einarsson, P., Roberts, M.J. and Sveinbjörnsson, H. (2010) Overview of Results from Continuous GPS Observations in Iceland from 1995 to 2010. Jökull, 60, 3-22.

[58] Metzger, S., Jónsson, S., Danielsen, G., Hreinsdóttir, S., Jouanne, F., Giardini, D. and Villemin, T. (2013) Present Kinematics of the Tjörnes Fracture Zone, North Iceland, from Campaign and Continuous GPS Measurements. Geophysical Journal International, 192, 441-455. https://doi.org/10.1093/gji/ggs032

[59] Rögnvaldsson, S., Gudmundsson, A. and Slunga, R. (1998) Seismotectonic Analysis of the Tjörnes Fracture Zone, an Active Transform Fault in North Iceland. Journal of Geophysical Research, 103, 117-130. https://doi.org/10.1029/98JB02789

[60] Stefánsson, R., Guðmundsson, G.B. and Halldórsson, P. (2008) Tjörnes Fracture Zone. New and Old Seismic Evidences for the Link between the North Iceland Rift Zone and the Mid-Atlantic Ridge. Tectonophysics, 447, 117-126. https://doi.org/10.1016/j.tecto.2006.09.019

[61] Jakobsdóttir, S.S. (2008) Seismicity in Iceland: 1994-2007. Jökull, 58, 75-100.

[62] Angelier, J., Bergerat, F. and Homberg, C. (2000) Variable Coupling Explains Complex Tectonic Regimes near Oceanic Transform Fault: Flateyjarskagi, Iceland. Terra Nova, 12, 97-101. https://doi.org/10.1046/j.1365-3121.2000.123279.x

[63] Garcia, S., Angelier, J., Bergerat, F. and Homberg, C. (2002) Tectonic Analysis of an Oceanic Transform Fault Zone Based on Fault-Slip Data and Earthquake Focal Mechanisms: The Húsavík-Flatey Fault Zone, Iceland. Tectonophysics, 344, 
157-174. https://doi.org/10.1016/S0040-1951(01)00282-7

[64] Homberg, C., Bergerat, F., Angelier, J. and Garcia, S. (2010) Fault Interaction and Stresses along Broad Oceanic Transform Zone: Tjörnes Fracture Zone, North Iceland. Tectonics, 29, TC1002. https://doi.org/10.1029/2008TC002415

[65] Ziegler, M., Rajabi, M., Heidbach, O., Hersir, G.P., Ágústsson, K., Árnadóttir, S. and Zanga, A. (2016) The Stress Pattern of Iceland. Tectonophysics, 674, 101-113. https://doi.org/10.1016/j.tecto.2016.02.008

[66] Tibaldi, A., Bonali, F.L., Einarsson, P., Hjartardóttir, Á.R. and Pasquarè Mariotto, F.A. (2016) Partitioning of Holocene Kinematics and Interaction between the Theistareykir Fissure Swarm and the Husavik-Flatey Fault, North Iceland. Journal of Structural Geology, 83, 134-155. https://doi.org/10.1016/j.jsg.2016.01.003

[67] Einarsson, P. (2008) Plate Boundaries, Rifts and Transforms in Iceland. Jökull, 58, 35-58.

[68] DeMets, C., Gordon, R.G., Argus, D.F. and Stein, S. (1994) Effect of Recent Revisions to the Geomagnetic Reversal Time Scale on Estimates of Current Plate Motions. Geophysical Research Letters, 21, 2191-2194.

[69] Jakobsson, S.P., Jónasson, K. and Sigurðsson, I.A. (2008) The Three Igneous Rock Series of Iceland. Jökull, 58, 117-138.

[70] McDougall, I., Sæmundsson, K., Jóhannesson, H., Watkins, N.D. and Kristjánsson, L. (1977) Extension of the Geomagnetic Time Scale to 6.5 m.y.: K-Ar Dating, Geological and Paleomagnetic Study of a $3500 \mathrm{~m}$ Lava Succession in Western Iceland. Geological Society of America Bulletin, 88, 1-15. https://doi.org/10.1130/0016-7606(1977)88<1:EOTGPT>2.0.CO;2

[71] Kristjánsson, L. (2008) Paleomagnetic Research on Icelandic Lava Flows. Jökull, 58, 101-116.

[72] Walker, G.P.L. (1960) Zeolite Zones and Dike Distribution in Relation to the Structure of the Basalts of Eastern Iceland. Journal of Geology, 68, 515-528. https://doi.org/10.1086/626685

[73] Walker, G.P.L. (1974) The Structure of Eastern Iceland. In: Kristjansson, L., Ed., Geodynamics of Iceland and the North Atlantic Area: NATO ASI, Reidel Publishing Company, Dordrecht, 177-188. https://doi.org/10.1007/978-94-010-2271-2_12

[74] Helgason, J. (1984) Frequent Shifts of the Volcanic Zone in Iceland. Geology, 12, 212-216. https://doi.org/10.1130/0091-7613(1984)12<212:FSOTVZ>2.0.CO;2

[75] Einarsson, P., Brandsdóttir, B. and Hjartardóttir, Á.R. (2016) The Seismogenic Fracture Systems of the Tjörnes Fracture Zone. International Workshop on Earthquakes in North Iceland, Húsavík, 31 May-3 June 2016, 3 p.

[76] Thoroddsen, Th. (1925) Die Geschichte der Isländischen Vulkane. Det Kongelige Danske Vidernskabernes Selskab, Höst og Sön, Copenhagen.

[77] Eiríksson, J. (1981) Lithostratigraphy of the Upper Tjörnes Sequence, North Iceland: The Breidavík Group. Acta Naturalia Islandica, 29, 37 p.

[78] Símonarson, L. and Eiríksson, J. (2008) Tjörnes-Pliocene and Pleistocene Sediments and Fauna. Jökull, 58, 331-342.

[79] Einarsson, P. and Björnsson, S. (1979) Earthquakes in Iceland. Jökull, 29, 37-43.

[80] Einarsson, P. (1991) Earthquakes and Present-Day Tectonism in Iceland. Tectonophysics, 189, 261-279. https://doi.org/10.1016/0040-1951(91)90501-I

[81] Icelandic Meteorological Office (IMO). SIL Network, Earthquakes and Volcanic Data. http://en.vedur.is/earthquakes-and-volcanism/earthquakes

[82] Tryggvason, E. (1973) Seismicity, Earthquake Swarms and Plate Boundaries in the 
Iceland Region. Bulletin of Seismological Society of America, 63, 1327-1348.

[83] Hjaltadóttir, S. and Vogfjörð, K. (2011) Fracture Mapping at Theistareykir and Bjarnarflag with High Resolution Location of Microearthquakes (in Icelandic). Landsvirkjun, Report LV-2011-116, 44 p.

[84] Geirsson, H., Árnadóttir, Th., Völksen, Ch., Jiang, W., Sturkell, E., Villemin, Th., Einarsson, P., Sigmundsson, F. and Stefánsson, R. (2006) Current Plate Movements across the Mid-Atlantic Ridge Determined from 5 Years of Continuous GPS Measurements in Iceland. Journal of Geophysical Research, 111, B09407.

[85] Metzger, S., Jónsson, S. and Geirsson, H. (2011) Locking Depth and Slip-Rate of the Húsavík-Flatey Fault, North Iceland, Derived from Continuous GPS Data 2006-2010. Geophysical Journal International, 187, 564-576.

[86] Sæmundsson, K. (1978) Fissure Swarms and Central Volcanoes of the Neovolcanic Zones of Iceland. In: Bowes, D.R. and Leake, B.E., Eds., Crustal Evolution in Northwestern Britain and Adjacent Regions, Geological Journal, Special Issue, Vol. 10, 415-432.

[87] Voight, B. and Mamula, N. (1983) Structure and Tectonics of Northeastern Iceland, In: Estes, J.E. and Thorley, G.A., Eds., Manual of Remote Sensing, 2nd Edition, Vol. 2, American Society of Photogrammetry, Falls Church, 1782-1786.

[88] Kristinsson, S.G., Óskarsson, F., Óladóttir, A.A. and Ólafsson, M. (2015) The High Temperature Geothermal Areas at Peistareykir, Krafla and Námafjall. Monitoring of Surface Geothermal Activity and Groundwater in the Year 2015 (in Icelandic). Iceland GeoSurvey, Report ÍSOR-2015/059, LV-2015-125, 175 p.

[89] Karlsdóttir, R., Vilhjálmsson, A.M., Árnason, K. and Beyene, A.T. (2012) Peistareykir Geothermal Area, Northern Iceland. 3D Inversion of MT Data. Report ÍSOR-2012/046, 173 p.

[90] Ármannsson, H. (2004) Chemical Aspects of Exploration of the Peistareykir High-Temperature Geothermal Area, N-E Iceland. In: Wanty, R.B. and Seal, R.R., Eds., Water-Rock Interaction, Taylor and Francis Group, London, 63-67.

[91] Karlsdóttir, R., Eysteinsson, H., Magnússon, I.P., Árnason, K. and Kaldal, I. (2006) TEM-Surveys at Peistareykir and Gjástykki 2004-2006 (in Icelandic). Report ÍSOR-2006/028, $87 \mathrm{p}$.

[92] Sæmundsson, K. (2007) Geology of Peistareykir (in Icelandic). Iceland GeoSurvey, Short Report ÍSOR-07270, 23 p.

[93] Guðmundsson, Á., Gautason, B., Lacasse, Ch., Axelsson, G., Porgilsson, G., Ármannsson, H., Tulinius, H., Sæmundsson, K., Karlsdóttir, R., Kjaran, S.P., Pálmarsson, S.Ó., Halldórsdóttir, S. and Egilson, P. (2008) Conceptual Model of the Geothermal Reservoir at Peistareykir and an Estimate of Stored Heat by Volume (in Icelandic). Iceland GeoSurvey, Report ÍSOR-2008/024, MV-049 Vatnaskil 08.05, 67 p.

[94] Mortensen, A.K. (2012) Peistareykir. Proposed Locations of Boreholes in the Geothermal Reservoir at Peistareykir (in Icelandic). Iceland GeoSurvey, Report ÍSOR-2012/043, $36 \mathrm{p}$.

[95] Sæmundsson, K., Sigurgeirsson, M.Á. and Grönvold, K. (2012b) Theistareykir, Geological Investigations 2011 (in Icelandic). Iceland GeoSurvey, Report ÍSOR-2012/024, $61 \mathrm{p}$, with map.

[96] Kristinsson, S.G., Friðriksson, Th., Ólafsson, M., Gunnarsdóttir, S.G. and Níelsson, S. (2013) High-Temperature Geothermal Fields of Peistareykir, Krafla and Námafjall: Monitoring of Surface Activity and Ground Water (in Icelandic). Iceland GeoSurvey, Report ÍSOR-2013/037, and Landsvirkjun LV-2013-091, 152 p.

[97] Rubin, A. (1992) Dike-Induced Faulting and Graben Subsidence in Volcanic Rift 
Zones. Journal of Geophysical Research, 97, 1839-1858. https://doi.org/10.1029/91JB02170

[98] Trippanera, D., Acocella, V., Ruch, J. and Abebe, B. (2015) Fault and Graben Growth along Active Magmatic Divergent Plate Boundaries in Iceland and Ethiopia. Tectonics, 34, 2318-2348. https://doi.org/10.1002/2015TC003991

[99] Khodayar, M. and Víkingsson, S. (2015) Note on Determining the Fracture Frequency in the Statistical Analysis of Large Fracture Populations. Iceland GeoSurvey, Short Report ÍSOR-15016, 8 p.

[100] Decriem, J., Árnadóttir, T., Hooper, A., Geirsson, H., Sigmundsson, F., Keiding, M., Ófeigsson, B.G., Hreinsdóttir, S., Einarsson, P., LaFemina, P. and Bennett, R.A. (2010) The 2008 May 29 Earthquake Doublet in SW Iceland. Geophysical Journal International, 181, 1128-1146. https://doi.org/10.1111/j.1365-246X.2010.04565.x

[101] Jóhannesson, H. (1982) Quaternary Volcanism in West Iceland (in Icelandic). In: Eldur er í norðri, Commemorative for Sigurður Pórarinsson, Sögufélagið, Reykjavík, 129-137.

[102] Khodayar, M. (2009) Geological Map of Hallarmúli Volcano, West Iceland: Bedrock, Tectonics and Unstable Plate Boundaries. Report ÍSOR-2009/060, 23 p, 1 Map $1: 20000$.

[103] Schuler, J., White, R.S., Brandsdóttir, B. and Tarasewicz, J. (2015) Shallow Geothermal and Deep Seismicity Beneath Peistareykir, NE-Iceland. Jökull, 65, 51-59.

[104] Ágústsson, K. and Guðnason, E.Á. (2016) Focal Mechanism of Selected Earthquakes at Peistareykir (in Icelandic). Iceland GeoSurvey, Short Report ÍSOR-16032, 5 p.

[105] Khodayar, M. (2018) Shift of a Rift by a Transform Zone: Case from Northern Rift Zone and Tjörnes Fracture Zone of Iceland. Petroleum Geoscience, Thematic Set: Rifts III: Catching the Wave, The Geological Society of London and EAGE, First published online April 2018, 11 p. https://doi.org/10.1144/petgeo2016-132

[106] Khodayar, M. and Einarsson, P. (2002) Strike-Slip Faulting, Normal Faulting, and Lateral Dike Injections along a Single Fault: Field Example of the Gljúfurá Fault near a Tertiary Oblique Rift-Transform Zone, Borgarfjörður, West Iceland. Journal of Geophysical Research, 107, ETG 5-1-ETG 5-16. https://doi.org/10.1029/2001JB000150

[107] Khodayar, M., Björnsson, S., Guðnason, E.Á., Níelsson, S., Axelsson, G. and Hickson, C. (2018) Tectonic Control of the Reykjanes Geothermal Field in the Oblique Rift of SW Iceland: From Regional to Reservoir Scales. Open Journal of Geology, 8 , 333-382. https://doi.org/10.4236/ojg.2018.83021

[108] Ármannsson, H., Kristmannsdóttir, H., Torfason, H. and Ólafsson, M. (2000) Natural Changes in Unexploited High-Temperature Geothermal Areas in Iceland. Proceedings World Geothermal Congress 2000, Kyushu, Tohoku, 28 May-10 June 2000, 521-526.

[109] Blischke, A. and Árnadóttir, S. (2012) PG-8 Televiewer and Composite Log Data Analysis: ABI-43 Acoustic Borehole Image and Lithology Log Data Processing and Interpretations for Depth Interval 1493.5 - 1775 m. Iceland GeoSurvey, Report ÍSOR-2012/020, 43 p + 2 Appendices.

[110] Níelsson, S., Egilson, P., Gunnarsdóttir, S.H., Stefánsson, H.Ö., Jónasson, H., Tryggvason, H. and Vilhjálmsson, S. (2011) Peistareykir-Well PG-8, Phase 3: Lithology and Logging. Drilling the Production Section with an 81/2" Bit from 1495 $\mathrm{m}$ to $2503 \mathrm{~m}$ Depth (in Icelandic). Iceland GeoSurvey, Report ÍSOR-2011/080, 67 p.

[111] Hermannsson, S. and Líndal, B. (1951) Chemical Analysis of Warm and Hot 
Springs (in Icelandic). Jarðboranir Ríkisins, State Drilling Company.

[112] Darling, W.G. and Ármannsson, H. (1989) Stable Isotopic Aspects of Fluid Flow in the Krafla, Námafjall and Theistareykir Geothermal Systems of Northeast Iceland. Chemical Geology, 76, 197-213. https://doi.org/10.1016/0009-2541(89)90090-9

[113] Júlíusson, E. (2015) Production tests at Theistareykir 2014-2015 (in Icelandic). Landsvirkjun, Short Report 2014-403/08.02.04, 5 p.

[114] Green, R.G., White, R.S. and Greenfield, T. (2014) Motion in the North Iceland Volcanic Rift Zone Accommodated by Bookshelf Faulting. Nature Geoscience, 7, 29-33. https://doi.org/10.1038/ngeo2012

[115] Khodayar, M. (2013) Fracture Analysis from Aerial Imageries and Correlation with Triggered Earthquakes by Injections at Húsmúli, Hengill, South Iceland. Iceland GeoSurvey, Report ÍSOR-2013/008, 23 p, 3 maps.

[116] Ágústsdóttir, Th., Woods, J., Greenfield, T., Green. R.G., White, R.S., Winder, T., Brandsdóttir, B., Steinthórsson, S. and Soosalu, H. (2016) Strike-Slip Faulting during the 2014 Bárðarbunga-Holuhraun Dike Intrusion, Central Iceland. Geophysical Research Letters, 43, 1495-1503. https://doi.org/10.1002/2015GL067423 